\title{
Submarine Earthquake History of the Çınarcık Segment of the North Anatolian Fault in the Marmara Sea, Turkey
}

\author{
by Laureen Drab, 'Aurélia Hubert-Ferrari, Sabine Schmidt, Philippe Martinez, \\ Julie Carlut, and Meriam El Ouahabi
}

\begin{abstract}
The North Anatolian fault (NAF) in the Marmara Sea is a significant hazard for the city of Istanbul. The use of paleoseismological data to provide an accurate seismic risk assessment for the area is constrained by the fact that the NAF system is submarine; thus a history of paleoearthquakes can be inferred only by using marine sediment cores. Here, a record of turbidites was obtained in two cores and used to reconstruct the earthquake history along the Çınarcık segment, a main branch of the NAF. Klg04 was collected from a berm north of the fault, and Klg03 was positioned in the Çınarcık basin, south of the fault. The cores were correlated using long-term geochemical variations in the sediment, and turbidites deposited simultaneously at both sites were then identified. Radionuclide measurements suggest the most recent turbidite was triggered by the 1894 C.E. $M_{\mathrm{w}} 7.3$ earthquake. We conclude that the turbidites identified at both sites are earthquake generated, based on their particular sedimentological and geochemical signatures; the correlation of turbidites at berm and basin sites; and the match of the most recent turbidite with a nineteenth century historical earthquake. To date older turbidites, we used carbon-14 and paleomagnetic data to build an OxCal model with a local reservoir correction of $400 \pm 50 \mathrm{yr}$. The Çınarcık segment is found to have ruptured in 1509 C.E., sometime in the fourteenth century, in 989 C.E., and in 740 C.E., with a mean recurrence interval in the range of 256-321 years. Finally, we used the earthquake record obtained to review the rupture history of the adjacent segments over the past 1500 years.
\end{abstract}

\section{Introduction}

Constraining the recurrence rate of $M_{\mathrm{w}}>7$ earthquakes that threaten the megacity of Istanbul is problematic because the late Holocene faults are submarine. Istanbul, with 12 million inhabitants, borders the Marmara Sea (Fig. 1a), a submarine pull-apart basin related to the North Anatolian fault (NAF), a major strike-slip fault that ruptures in large magnitude earthquakes. Since the $1999 M_{\mathrm{w}} 7.4$ Izmit earthquake, stresses have further increased in the eastern part of the Marmara Sea (Hubert-Ferrari et al., 2000; Parsons et al., 2000; Pondard et al., 2007). Understanding past ruptures of the NAF in the Marmara Sea is thus a key issue in assessing seismic hazards for this area.

Subaqueous paleoseismology can reconstruct the history of large earthquakes on submarine faults (Goldfinger, 2011), as shaking associated with large offshore earthquakes triggers submarine landslides and turbidity currents. The resulting deposits can be sampled by sediment coring, characterized, and dated. Earthquake-generated turbidites have

*Now at Lamont Doherty Earth Observatory, Columbia University, 61 Route 9W Palisades, New York 10964; 1drab@ldeo.columbia.edu. generally been identified based on their synchronicity at different sites and their distinctive sedimentological or geochemical signatures (Gorsline et al., 2000; Nakajima and Kanai, 2000; Shiki et al., 2000; Beck et al., 2007; Masson et al., 2011; Drab et al., 2012). In the case of the Marmara Sea, several studies (McHugh et al., 2006; Sarı and Çağatay, 2006; Beck et al., 2007; Drab et al., 2012) revealed that its sediments contain a record of turbidites triggered by large earthquakes. These turbidites have been used to constrain the history of earthquakes rupturing across a given depocenter (McHugh et al., 2006; Drab et al., 2012). The present study shows that marine sediment cores can be used to constrain paleoruptures of the NAF segment located just south of Istanbul and to evaluate the recurrence rate of large magnitude earthquakes in this area.

Here, we apply subaqueous paleoseismology to two gravity cores located in the Çinarcık basin of the Marmara Sea (Fig. 1b). The Çınarcık basin is located $\sim 20 \mathrm{~km}$ to the south of Istanbul and is north bounded by the Çinarcık fault, the main segment of the NAF. In the two cores, we identified and characterized turbidite deposits using their grain size and 

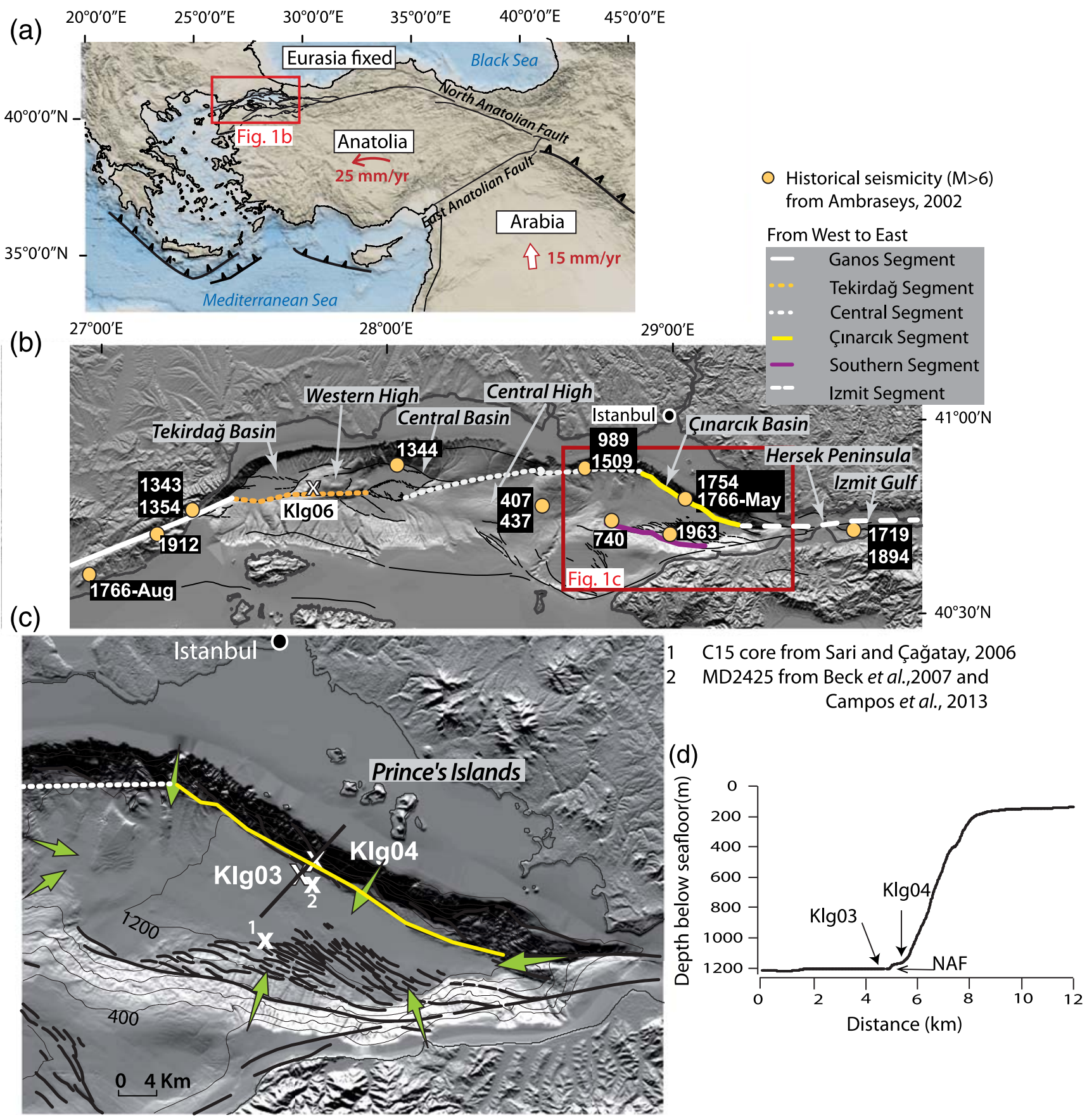

Figure 1. (a) Global geodynamic context of the Anatolian plate with Global Positioning System velocities from Reilinger et al. (2006). The location of the Marmara Sea (shown in [b]) is indicated with a box. (b) General tectonic map of the Marmara Sea, crossed by the North Anatolian fault (NAF). Basins, highs, and main segments of the fault are indicated from the west to the east with different lines, and their names are given in the gray box to the right. The study area (shown in [c]) is depicted with a box. Historical earthquakes located by Ambraseys (2002) are represented with rupture dates and dots. (c) The map of Çinarcık basin. Location of the two studied cores is represented with respect to the Çınarcık fault segment. Arrows show sediment paths for turbidite deposits (Altınok et al., 2011). The line crossing the two cores represents the topographic profile presented in (d). White crosses represent the location of other published cores discussed in the study. (d) Topographic profile of the northern part of the Çınarcık basin. The profile starts close to the center of the Çınarcık basin. The color version of this figure is available only in the electronic edition.

geochemical characteristics. We also used east Mediterranean-scale changes in sedimentation to correlate the two records to a reference core located in a nonturbidite depositional environment. We then investigated the possible trig- gering mechanisms of the turbidites. Radiogenic lead $\left({ }^{210} \mathrm{~Pb}\right)$ and cesium $\left({ }^{137} \mathrm{Cs}\right)$ data allowed us to date and correlated the turbidites at the top of the sediment columns with recent historical earthquakes. Radiocarbon dating $\left({ }^{14} \mathrm{C}\right)$ combined 
with paleomagnetic data enabled us to construct an age model for the core Klg04 located in a berm in the Çinarcik fault scarp (Fig. 1c,d) and to date turbidites over the last 1500 years. Finally, the NAF rupture behavior in the Marmara Sea is discussed.

\section{Setting}

\section{Tectonic and Paleoseismological Background}

The NAF is a major dextral strike-slip fault extending over $1200 \mathrm{~km}$ in northern Turkey and in the Aegean Sea (Barka and Kadinsky-Cade, 1988; Sengör et al., 2005) (Fig. 1a). In the Marmara Sea, the NAF accommodates a dextral horizontal motion of $18.5 \mathrm{~mm} / \mathrm{yr}$ (Kurt et al., 2013) spread over a width of $130 \mathrm{~km}$ (Barka and Kadinsky-Cade, 1988). Most of the deformation is localized on the northern branch of the NAF (Armijo et al., 2002), which crosses the Marmara Sea. The Marmara Sea is 170 km long, has a maximum water depth of $1250 \mathrm{~m}$, and is composed of three aligned pull-apart basins separated by two topographic ridges (Le Pichon et al., 2001; Armijo et al., 2002; Sarı and Çağatay, 2006; Fig. 1b).

The study focuses on the Çinarcık basin, the easternmost transform basin of the Marmara Sea (Fig. 1c). The $50 \mathrm{~km}$ long $\times 18 \mathrm{~km}$ wide basin is bounded to the north by the main segment of the NAF and to the south by a secondary normal fault system (Smith et al., 1995; Le Pichon et al., 2001; Armijo et al., 2002). The main northern segment, here called the Çinarcık segment, runs at the base of a steep escarpment, $1000 \mathrm{~m}$ high (from 200 to 1200 meters below sea level [m.b.s.l.]) and $40 \mathrm{~km}$ long. The fault is characterized by composite strike-slip and normal motions (Armijo et al., 2002).

In the last 300 years, the Çınarcık basin has experienced several $M_{\mathrm{w}}>6$ earthquakes (Ambraseys, 2002; Fig. 1a). The most recent 1963 C.E. $M_{\mathrm{w}} 6.3$ earthquake occurred on the southern fault bordering the Çinarcık basin (Bulut and Aktar, 2007; Fig. 1a). Presently, this is the only earthquake unambiguously attributed to a fault in the Çınarcık basin. The 1894 C.E. $M_{\mathrm{w}} 7.3$ earthquake has been located in the Çınarcık basin (Parsons, 2004; Hebert et al., 2005; Pondard et al., 2007) or in the Izmit Gulf (Hubert-Ferrari et al., 2000; Ambraseys, 2002; McHugh et al., 2006). The associated tsunami strongly affected the Prince Islands, south of Istanbul (Ambraseys, 2002; Altınok et al., 2011). During the eighteenth century, there was a westward-propagating sequence of earthquakes in the Marmara Sea (1719 C.E., 1754 C.E., May and August 1766 C.E.), but the corresponding fault ruptures are poorly constrained. In 1509 C.E., a large earthquake destroyed Istanbul; its epicenter has been located near the city (Ambraseys, 2001, 2009), but it may have ruptured either the Çınarcık or the Central faults (Guidoboni and Comastri, 2005). Destruction associated with the 1343 C.E. earthquake was mostly on the western part of the Marmara Sea, but this earthquake was associated with a large burst of seismicity during the end of the thirteenth and fourteenth centuries in the Marmara area (Ambraseys and Finkel, 1991). The 989 C.E. earthquake principally affected the Istanbul region, with a tsunami reaching the city (Ambraseys and Finkel, 1991; Altınok et al., 2011). Historical data predominantly locate the event in the Çinarcık basin (Ambraseys, 2002; Guidoboni and Comastri, 2005). Finally, the 740 $M_{\mathrm{w}} 7.1$ C.E. earthquake was associated with a large tsunami (Altınok et al., 2011). It has been generally located in the Çınarcık basin (Ambraseys, 2002; Guidoboni and Comastri, 2005), but some authors suggested an epicenter location in the Izmit Gulf or Central basin (McHugh et al., 2006; Bertrand et al., 2011; Çă̆atay et al., 2012). Historical information for older ages is limited, but Ambraseys (2002) located the 407 C.E. and 437 C.E. earthquakes in the Çınarcık basin.

Based only on historical reports, it is difficult to unambiguously associate an offshore earthquake with a given submarine fault (Table 1). Even studies combining historical data with attenuation models (Parsons, 2004) or distribution of slip deficit and Coulomb stress interaction (Pondard et al., 2007) propose different rupture scenarios across the Marmara Sea. Subaqueous paleoseismological studies provide additional constraints. Indeed, in the Marmara Sea, earthquaketriggered turbidites have been documented by McHugh et al. (2006), Sarı and Çağatay (2006), Beck et al. (2007), and Drab et al. (2012). In addition McHugh et al. (2006) and Drab et al. (2012) found that large earthquakes rupturing the bounding or crossing fault of a given basin strongly affect its sedimentation but have minor or no effects on the nearby sedimentary basins. Thus, a series of individual seismoturbidites can be linked to a specific earthquake rupture associated with large historical earthquakes.

\section{Seismoturbidite Characteristics}

In general, turbidites are often interpreted to have a seismic trigger because of their broad contemporaneous occurrence in a given setting (Goldfinger, 2011) and of their particular sedimentological imprint. In the Marmara Sea, the geographical extent of turbidite deposits has been deduced by correlating different sediment cores or by using highresolution seismic subbottom profiles for imaging fine transparent layers related to turbidite deposits (McHugh et al., 2006; Beck et al., 2007).

Seismoturbidites are generally distinctive from nonearthquake-triggered slope failure turbidites because of their specific sedimentological and mineralogical imprints. They are characterized primarily by complex laminae (Shiki et al., 2000; McHugh et al., 2011); sharp basal layers (Shiki et al., 2000); multiple coarse bases enriched with shells and detrital material, indicating multiple sources (Nakajima and Kanai, 2000; Bertrand et al., 2008; Goldfinger et al., 2008); variation in the composition of detrital material between each event (Nakajima and Kanai, 2000); and abrupt changes in sedimentary structures (Nakajima and Kanai, 2000; Shiki et al., 2000). 


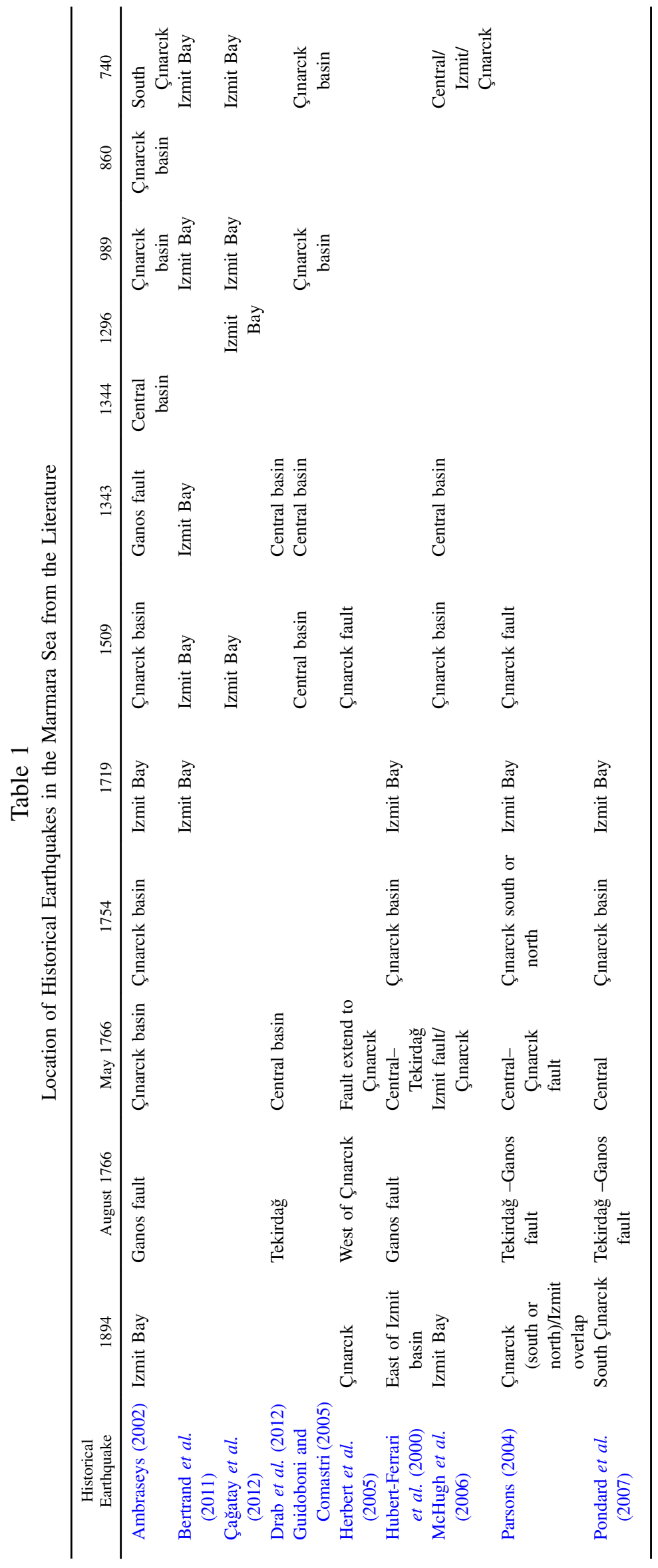


Seismoturbidites in the Marmara Sea have been distinguished from other turbidites based on their particular grain size and geochemical characteristics (Sarı and Çağatay, 2006; Beck et al., 2007; Çağatay et al., 2012). The seismoturbidites deposited in the Central and Tekirdağ basins have the following specific characteristics (Drab et al., 2012): (1) they display nongradational changes in particles size and coarse basal pulse; (2) intermediate silt-rich layers show numerous thin parallel laminae and flaser-bed structures linked to oscillating currents (Beck et al., 2007; Campos et al., 2013); (3) sharp basal sand layers are characterized by a decrease in bromine $(\mathrm{Br})$ content, a relative increase in titanium (Ti), a peak in zirconium ( $\mathrm{Zr}$ ), and magnetic susceptibility (Çağatay et al., 2012; Campos et al., 2013); and (4) the turbidite is capped by a clayey silt layer. Turbidites induced by earthquakes in the Izmit Gulf have the same characteristics and show a large peak in manganese below the base of the turbidite related to a transient reduction front following the turbidite deposit (Çă̆atay et al., 2012). Finally, these seismoturbidites are synchronous with distal finegrained deposits in the adjacent Western High that are related to a thick suspension cloud above the turbidite flow (McHugh et al., 2011; Drab et al., 2012).

In the Çınarcık basin, the record of turbidites has not been studied in detail yet, but Sarı and Çağatay (2006) identified reworked deposits in sediment cores and inferred a seismic trigger due to (1) the increase in different detrital material at the base of their events, (2) the occurrence of shallow benthic foraminifers, and (3) the exclusion of any other possible triggering mechanism.

Paleo-Environmental Changes Recorded in the Marmara Sea

Evidence for the simultaneous deposition of sediment can be established in the Maramara Sea cores because Holocene sedimentation displays distinct and important changes. For the last $4 \mathrm{ka}$, most of these changes have been related to anthropogenic disturbances (Mudie et al., 2002; Kazanci et al., 2004; Valsecchi et al., 2012).

Pollen studies (Mudie et al., 2002; Valsecchi et al., 2012) documented two phases of forest clearance. The first phase occurred from 5 to 4 ky B.P. The second one started around $2.5 \mathrm{ka}$ and marked the first appearance of sustained agriculture along the Marmara Sea coasts (Mudie et al., 2002, 2007; Valsecchi et al., 2012). Forest clearance was associated with significant land degradation in the Marmara Sea catchments (Kazanci et al., 2004; Valsecchi et al., 2012). These changes in vegetation and land use triggered an increase in sedimentary flux to the Marmara Sea (Walling, 2006) and resulted in a progressive increase in sedimentation rate on the Marmara southern shelf (Kazanci et al., 2004). In addition, about $2 \mathrm{ka}$ ago, a global increase in grain size synchronous with a step increase in lead and titanium was described in the Marmara Sea deep basins (Fig. 2; Drab et al., 2012).
The sedimentary imprints of the different environmental changes are summarized in Figure 2, using data from the core Klg06 published in Drab et al. (2012) and the core MD012430 published in Vidal et al. (2010) and Valsecchi et al. (2012). The two cores are located on the Marmara Sea structural Western High, are devoid of any significant turbidites, and contain a continuous record of environmental changes. Drab et al. (2012) have shown that these global environmental changes are synchronous in the different basins of the Marmara Sea and can be tracked through x-ray fluorescence (XRF) measurements. As a consequence, common time horizons between sediment cores can be defined and used to match turbidites in a given depocenter.

\section{Coring Site and Methods}

Two Kullenberg sediment piston cores, Klg03 and $\mathrm{K} \lg 04$, were collected in the Çinarcık basin during the Marmarascarps cruise in 2002 (Armijo et al., 2005), shortly after the $1999 M_{\mathrm{w}} 7.4$ Izmit earthquake (Fig. 1a, Table 2). They are $3 \mathrm{~km}$ apart and lie along the Çinarcik fault segment bordering the northern edge of the basin. Core Klg03 is located in the deepest part of the main Holocene depocenter (1240 m.b.s.l.; Carton et al., 2007), $1.6 \mathrm{~km}$ south of the main fault strand. The site is on the main path of turbidites coming from the northern shelf, but it can also be reached by turbidites generated on the Central High or on the southern slope (Fig. 1c). Core Klg04 is located in a topographic berm between two splays of the Çınarcık segment near the base of the $1000 \mathrm{~m}$ high northern slope in front of the Prince Islands (Fig. 1c). It lies $300 \mathrm{~m}$ north of the main fault segment and is $35 \mathrm{~m}$ higher than the Klg03 site (Fig. 1d). Because the $\mathrm{Klg} 04$ site is placed significantly above the basin floor, it can be reached only by turbidites originating from the northern shelf.

In this article, we also used data from core $\mathrm{Klg} 06$, located on the Western High, $100 \mathrm{~km}$ away from the Çınarcık basin (Fig. 1b). The core spans the last $7 \mathrm{ky}$ and does not contain a record of coarse-grained turbidites like the ones deposited in the basins of the Marmara Sea (Drab et al., 2012). Core Klg06 is thus used to highlight global environmental changes that occurred in the Marmara Sea and to provide common time horizons in-between the $\mathrm{K} \lg 03$, $\mathrm{K} \lg 04$, and $\mathrm{Klg} 06$ cores.

A number of sedimentological investigations were performed to describe and characterize turbidites in the cores. $\mathrm{X}$-ray radiographs obtained on the scopix system at Environnements et Paloenvironnements Ocaniques et Continentaux (EPOC) research group in the University of Bordeaux were used to identify turbidites, similar to methods used by Beck et al. (2007) and Drab et al. (2012). Grain size measurements were performed on bulk sediment every centimeter on a Malvern Mastersizer 2000 to support the identification of turbidites (Folk, 1968; Sperazza et al., 2004; Bertrand et al., 2008). Magnetic susceptibility measurements were obtained on split cores using a Bartington MS2E every $5 \mathrm{~mm}$ at room 


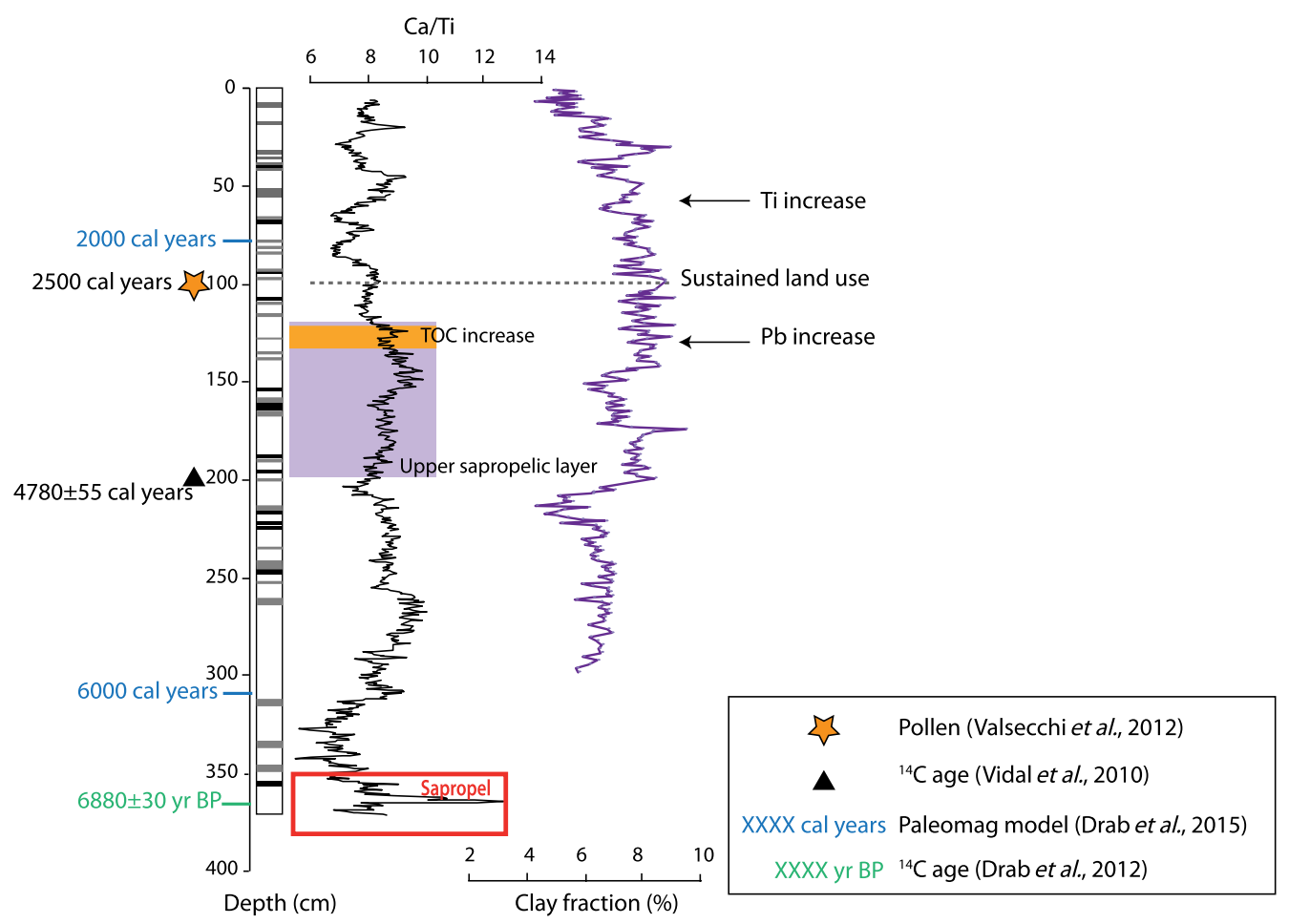

Figure 2. Summary of major Holocene sedimentation changes observed in core Klg06 with x-ray fluorescence (XRF), grain size, and total organic carbon content. Ages obtained from different studies (Vidal et al., 2010; Drab et al., 2012; Valsecchi et al., 2012; Drab et al., 2015) are indicated on the left side of the log. The color version of this figure is available only in the electronic edition.

temperature and highlight beds enriched in magnetite, which accompanies coarse detrital material that can characterize the base of turbidites (Evans and Heller, 2003). XRF data were acquired using an Avaatech XRF core scanner and were used to describe geochemical and sedimentological processes associated with earthquake-related deposits by comparing elements considered as detrital with more local ones, like calcium. Measurements were taken every $5 \mathrm{~mm}$ with radiation energies of 10 and $30 \mathrm{keV}$ to reach a large spectrum of elements comprising calcium (Ca), Ti, manganese (Mn), and $\mathrm{Zr}$. Because the XRF data need to be compared through and between the sediment cores regardless of the absolute value of the concentrations, we standardized the data to have a zero mean and unit variance. We also used ratios of elements that provide the most easily interpretable signal of relative changes in chemical composition and minimize the risk of drawing erroneous conclusions by enhancing the signalto-noise ratio (Palike et al., 2001; Vlag et al., 2004; Bahr et al., 2005).

Table 2

Location of Kullenberg Cores

\begin{tabular}{ccccc}
\hline Core & $\begin{array}{c}\text { Latitude } \\
\left({ }^{\circ} \mathrm{N}\right)\end{array}$ & $\begin{array}{c}\text { Longitude } \\
\left({ }^{\circ} \mathrm{E}\right)\end{array}$ & $\begin{array}{c}\text { Water Depth } \\
(\mathrm{m})\end{array}$ & $\begin{array}{c}\text { Core Depth } \\
(\mathrm{cm})\end{array}$ \\
\hline Klg03 & $40^{\circ} 47.98$ & $28^{\circ} 59.55$ & 1241 & 374 \\
$\mathrm{~K} \lg 04$ & $40^{\circ} 48.60$ & $29^{\circ} 00.73$ & 1206 & 419 \\
$\mathrm{~K} \lg 06$ & $40^{\circ} 48.90$ & $27^{\circ} 44.28$ & 726 & 371 \\
\hline
\end{tabular}

The chronology of the sediment cores is based on ${ }^{210} \mathrm{~Pb}$, ${ }^{137} \mathrm{Cs}$, and ${ }^{14} \mathrm{C}$ analyses and paleomagnetic measurements. The ${ }^{210} \mathrm{~Pb}$ and ${ }^{137} \mathrm{Cs}$ radionuclides were measured using a semiplanar $\gamma$ detector (University of Bordeaux 1) at EPOC (Schmidt et al., 2009). Paleomagnetic measurements (secular variation of the geomagnetic inclination and declination) provided independent time constraints. The natural remanent magnetization (NRM) was measured on $1.5 \mathrm{~m}$ long U-channel samples cut from cores using a horizontal cryogenic magnetometer 2G-enterprise at the paleomagnetic laboratory of the Institut de Physique du Globe de Paris. Measurements were performed every $2 \mathrm{~cm}$. The NRM was progressively demagnetized using an alternating field in 11 steps up to a maximum field peak of $90 \mathrm{mT}$ on $\mathrm{Klg} 04$. The characteristic remanent magnetization (ChRM) was then isolated using Zijderveld diagrams and least-squares principal component analysis (Kirschvink, 1980; Cogné, 2003). (Zijderveld diagrams are presented in Fig. A1). Core Klg03 was also analyzed, but only two demagnetization steps were applied because of technical issues.

Accelerator mass spectrometry radiocarbon dating on 24 samples (benthic foraminifers, planktonic foraminifers, and mollusk shells) was carried out at Artemis LMC14 laboratory in Laboratoire des Sciences du Climat et de l'Environnement, Orsay, and at the Aeon laboratory (Table 3). Both planktonic and benthic foraminifers were collected when possible in hemipelagic sediments just above the turbidites. Mollusk shells were mostly extracted at the base 


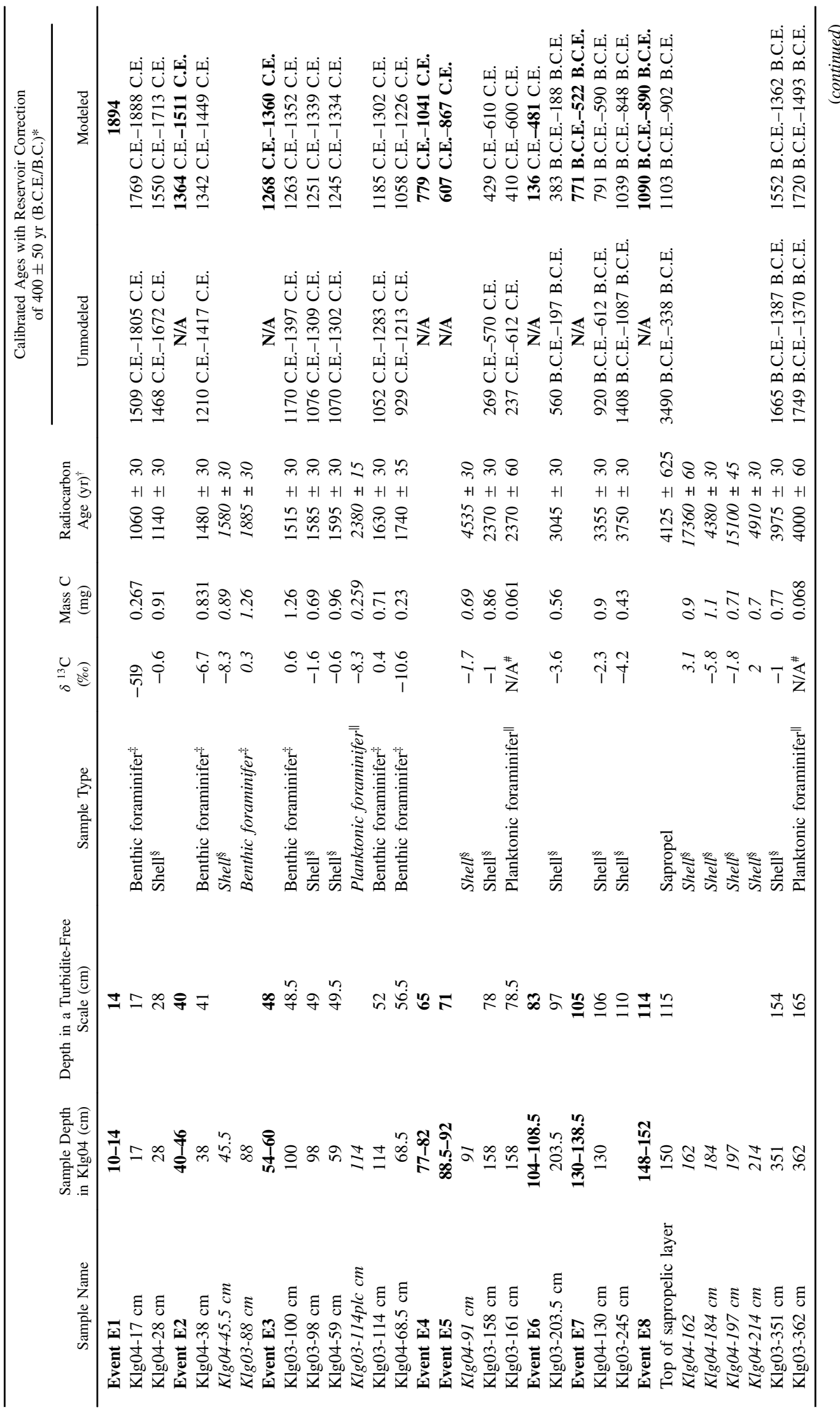




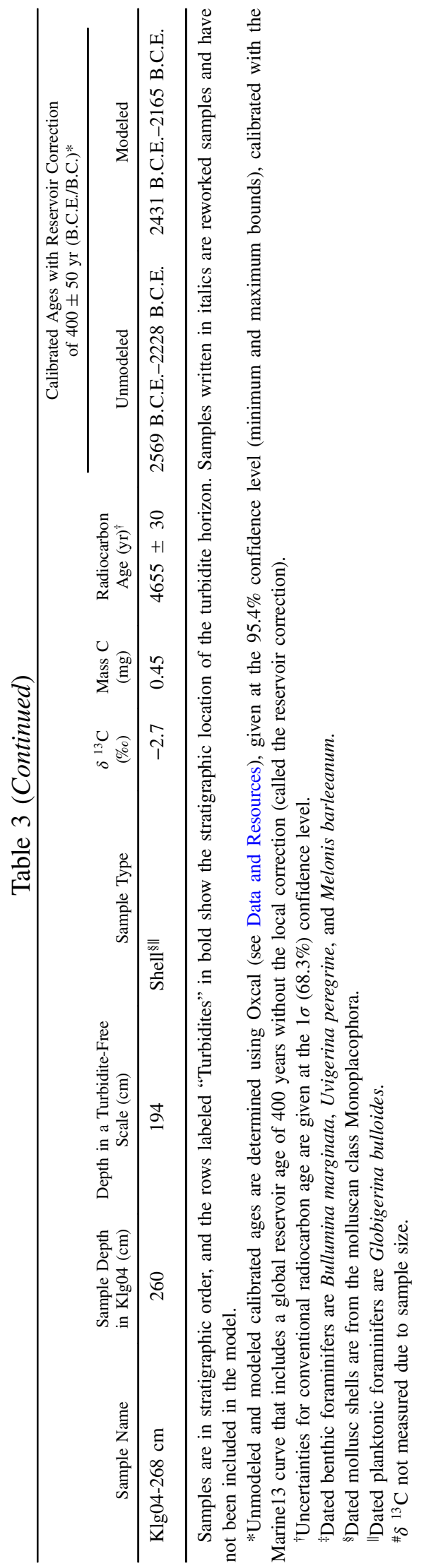

of turbidites. Samples were selected in the first $150 \mathrm{~cm}$ of the two sediment cores to be able to relate recorded turbidites with historical earthquakes for which the segment ruptures may not be well constrained. Ages were calibrated using OxCal with the Marine13 calibration curve (Reimer et al., 2013). Because two different samples types (mollusk shells and Globigerina bulloides planktonic foraminifers) collected at the same depths $(160$ and $350 \mathrm{~cm})$ gave the same ${ }^{14} \mathrm{C}$ age (Table 3), we assumed that the reservoir effect is the same for shells, planktonic, and benthic foraminifers up to 2000 yr B.P.

\section{Results}

Sedimentology, Physical and Chemical Properties of Turbidites

Visual inspection shows that all sediment cores have mostly uniform silty-clay lithology with few sandy laminae containing shell fragments (indicated by a star in Fig. 3 and arrows on the logs in Figs. 4 and 5). However, x-ray imagery combined with grain size measurements indicate that sediments are composed of a succession of rapidly deposited layers (i.e., turbidites). Turbidite deposits are usually characterized by a basal dark gray sandy layer and are followed by a grayer silt layer. The sand layer displays collocated high magnetic susceptibility and zirconium values, as well as a peak of manganese below the basal layer (Figs. 3, 4, and 5; Çağatay et al., 2012). All of the sandy bases in Klg04, and most of those in Klg03, display a sharp lower boundary, some of which are irregular, indicating erosion associated with strong disturbances in the sediment structure (see rectangles on the right side of the logs in Figs. 4 and 5, showing major disturbances seen on $\mathrm{x}$-ray images). This sandy base also appears in $50 \%$ of the turbidites in $\mathrm{Klg} 04$ and $30 \%$ in Klg03 multiple coarse pulses (Figs. 3b, 4, and 5). The overlying silt layers in $\mathrm{Klg} 03$ frequently show numerous thin parallel laminae, greater in concentration near their base. Beck et al. (2007) linked these laminae to the to-and-from bottom displacement induced by oscillating earthquake-triggered currents. In Klg04, overlying silt layers exhibit mostly turbulent deposition. In both cores, the silt layers reach a maximum in grain size just above the basal layer and can be capped by a thin light-gray clayey layer that is not easily distinguishable from hemipelagic sediments.

In core $\mathrm{K} \lg 03$, we also identify a few sandy layers that do not show an erosive base (named tA, tB, tC, and tD in Fig. 4); these turbidites only contain laminae that are $2-5 \mathrm{~cm}$ thick. In addition, very thin sand laminae ( $\sim 2 \mathrm{~cm}$ thick) that may correspond to minor turbidites are observed in the sediments. They typically have less than half of the thickness of the smallest major turbidite $(\sim 5 \mathrm{~cm})$ identified in the same core.

Turbidite deposits comprise about $40 \%$ of the sediment record of $\mathrm{K} \lg 03$ and $\mathrm{K} \lg 04$ cores. The $370 \mathrm{~cm}$ long Klg03 core shows 14 erosive-base turbidites, with thicknesses ranging from 4 to $8 \mathrm{~cm}$, and four nonerosive base turbidites 
(a)

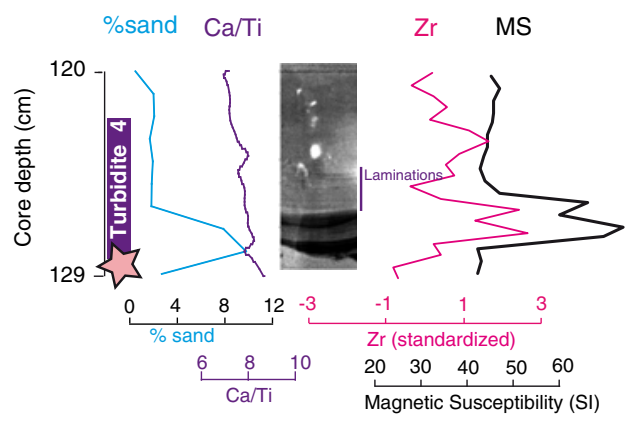

(b)

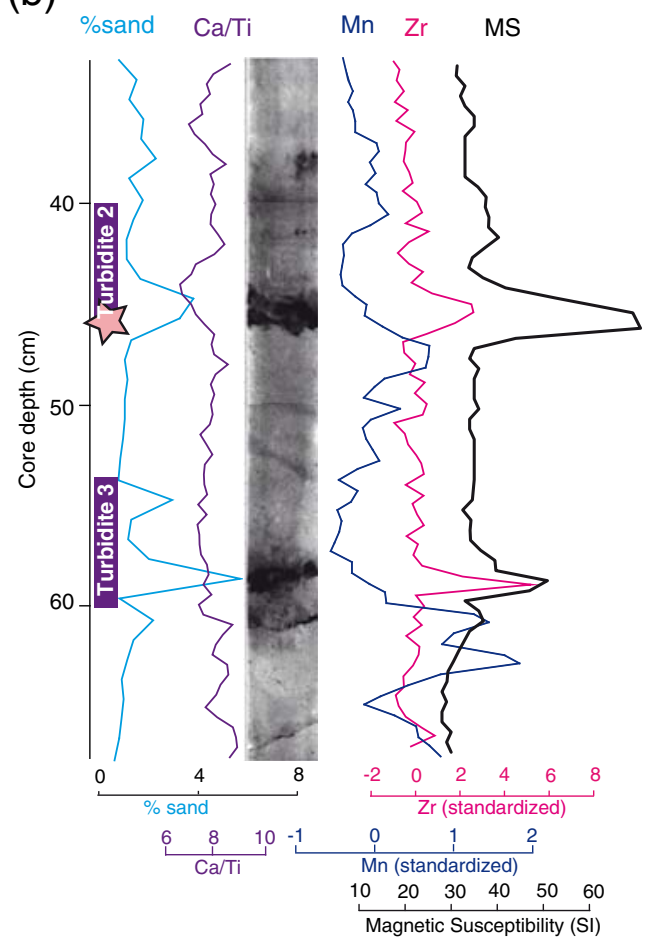

Figure 3. Typical examples of turbidites: grain size and geochemical (Ca/Ti, Mn, $\mathrm{Zr}$, and magnetic susceptibility) signatures. Turbidites are composed of a basal sand layer, an upper silt layer with frequent laminations, and an upper light-gray clayey layer. (a) X-ray imagery, grain size, and geochemical profiles of turbidite e4 at $120 \mathrm{~cm}$ depth in Klg03. (b) X-ray imagery, grain size, and geochemical profiles of turbidite e 2 at $45 \mathrm{~cm}$ depth in $\mathrm{Klg} 04$. Manganese typically shows a peak just below turbidites. The color version of this figure is available only in the electronic edition.

(Fig. 4). Twenty-three turbidites are recorded in Klg04, with thicknesses ranging from 3 to $8 \mathrm{~cm}$ (Fig. 5).

\section{Correlation of Cores and Turbidites}

The cores $\mathrm{Klg} 03$ and $\mathrm{Klg} 04$ were correlated with the Klg06 reference core based on the occurrence of synchronous global changes in the sedimentation (Fig. 6). Among these changes, a sapropelic layer is clearly identified in $\mathrm{Klg} 04$ and $\mathrm{Klg} 03$ cores. Sapropelic layers are organic-rich layers commonly found in the Mediterranean area (Rohling and Hilgen, 1991; Cramp and O'Sullivan, 1999; Larrasoaña et al., 2003) and in the Marmara Sea (Çağatay et al., 2000; Tolun et al., 2002; Vidal et al., 2010). The last referenced sapropelic layer was identified by Çağatay et al. (2000) and occurred between 4.7 and $3.2 \mathrm{ky}$ in the Marmara Sea. We identified the last sapropelic layer in the cores by an increase in total organic carbon content (Drab, 2012; Drab et al., 2015). The layer is mapped in Figure 6 and can be used as an independent time constraint for the core chronology.

Paleomagnetic measurements obtained on the $\mathrm{Klg} 03$ and $\mathrm{Klg} 04$ cores also display important variations in the magnetic properties. A drop of magnetization in the NRM data is observed at $250 \mathrm{~cm}$ in $\mathrm{Klg} 03$ and at $80 \mathrm{~cm}$ in $\mathrm{K} \lg 04$ (Fig. 6) and corresponds to the dissolution of magnetite grains through the process of diagenesis in the sediment.
The origin of the magnetic drop has been extensively studied by Drab (2012) and Drab et al. (2015). The occurrence of the very low magnetization is linked to the deposition of organicrich material forming a sapropelic layer (Cramp and O'Sullivan, 1999; Larrasoaña et al., 2003).

In addition, a global increase in grain size is identified in the cores and is linked with the deforestation and growth in sediment flux observed for the last $2 \mathrm{ka}$ (Kazanci et al., 2004; Walling, 2006; Valsecchi et al., 2012). Finally, we used XRF data to identify other correlative changes in the $\mathrm{Klg} 04$ and $\mathrm{Klg} 03$ cores (Fig. 6). First, the upper part of the cores shows an increase in $\mathrm{Br}$, representing an increase in organic matter (Ziegler et al., 2008; Drab et al., 2012). Second, both cores show a wide peak in $\mathrm{Sr}$ above the upper sapropelic layer. Third, the two cores were correlated based on the variation of $\mathrm{Ca} / \mathrm{Ti}$ ratio and $\mathrm{Br}$ content (Bahr et al., 2005; Gracia et al., 2010). In the Marmara Sea, long-term regional variations in the $\mathrm{Ca} / \mathrm{Ti}$ ratio are related to environmental changes, and Drab et al. (2012) have shown that the record for the $\mathrm{Klg} 04$ core can be linked to the $\mathrm{Klg} 06$ core in the Western High. The $\mathrm{Ca} / \mathrm{Ti}$ curve in $\mathrm{Klg} 04$ is very spiky compared with the $\mathrm{K} \lg 06$ one, which could be linked to basal erosion during turbidite emplacement. Figure 6 shows the correlation of $\mathrm{Klg} 03$ and $\mathrm{Klg} 04$ cores, excluding the coarse turbidites from the record. The XRF variations in $\mathrm{Klg} 06$ core are also displayed as a reference. 


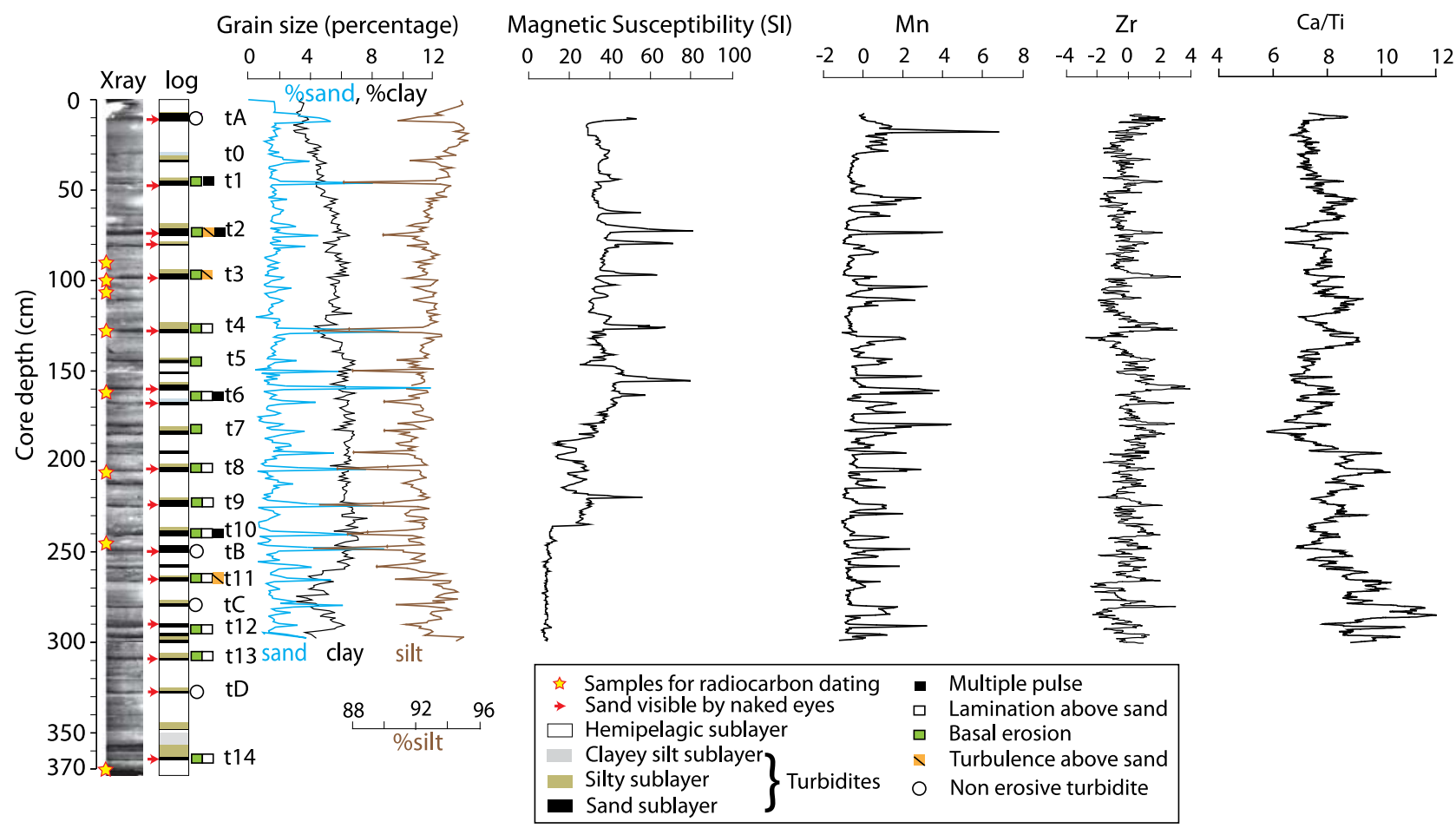

Figure 4. Stratigraphic interpretation of core Klg03 obtained combining X-ray imagery, particle size, magnetic susceptibility data, Ca/Ti, $\mathrm{Mn}$, and $\mathrm{Zr}$ standardized intensities. Major turbidites are labeled, beginning with 1 at the top of the core, whereas turbidites without erosive base are labeled with a capital letter. Sand layer names are given when the percentage of sand is greater than the background percentage. Descriptions of the turbidites seen in the x-ray radiographs are also given with different symbols on the right side of the core log. The color version of this figure is available only in the electronic edition.

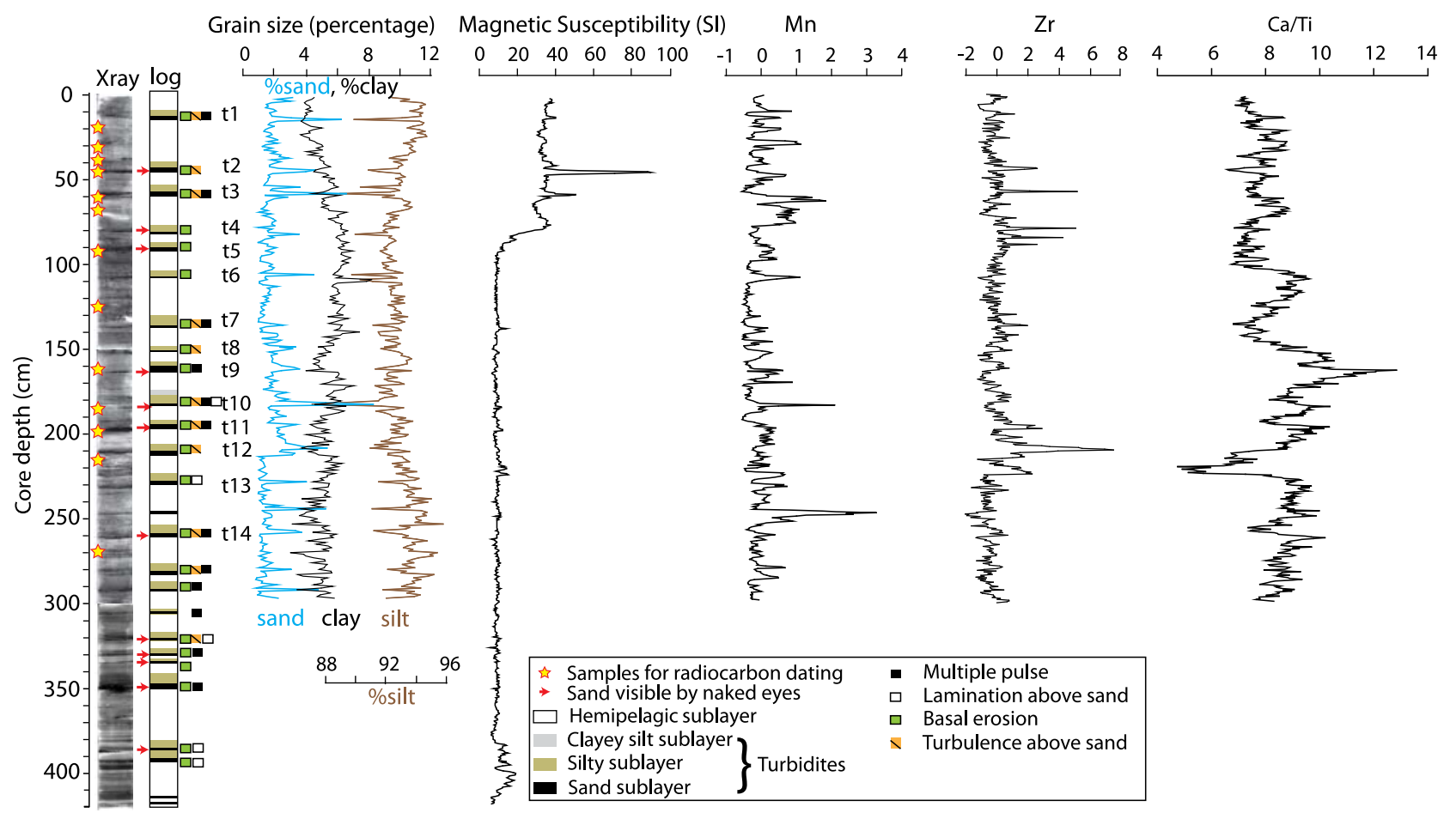

Figure 5. Stratigraphic interpretation of core Klg04 obtained combining x-ray imagery, particle size, magnetic susceptibility data, Ca/Ti, $\mathrm{Mn}$, and $\mathrm{Zr}$ standardized intensities. Major turbidites are labeled, beginning with 1 at the top of the core. Sand layer names are given when the percentage of sand is greater than the background percentage. Descriptions of the turbidites seen in the x-ray radiographs are also given with different symbols on the right side of the core log. The color version of this figure is available only in the electronic edition. 


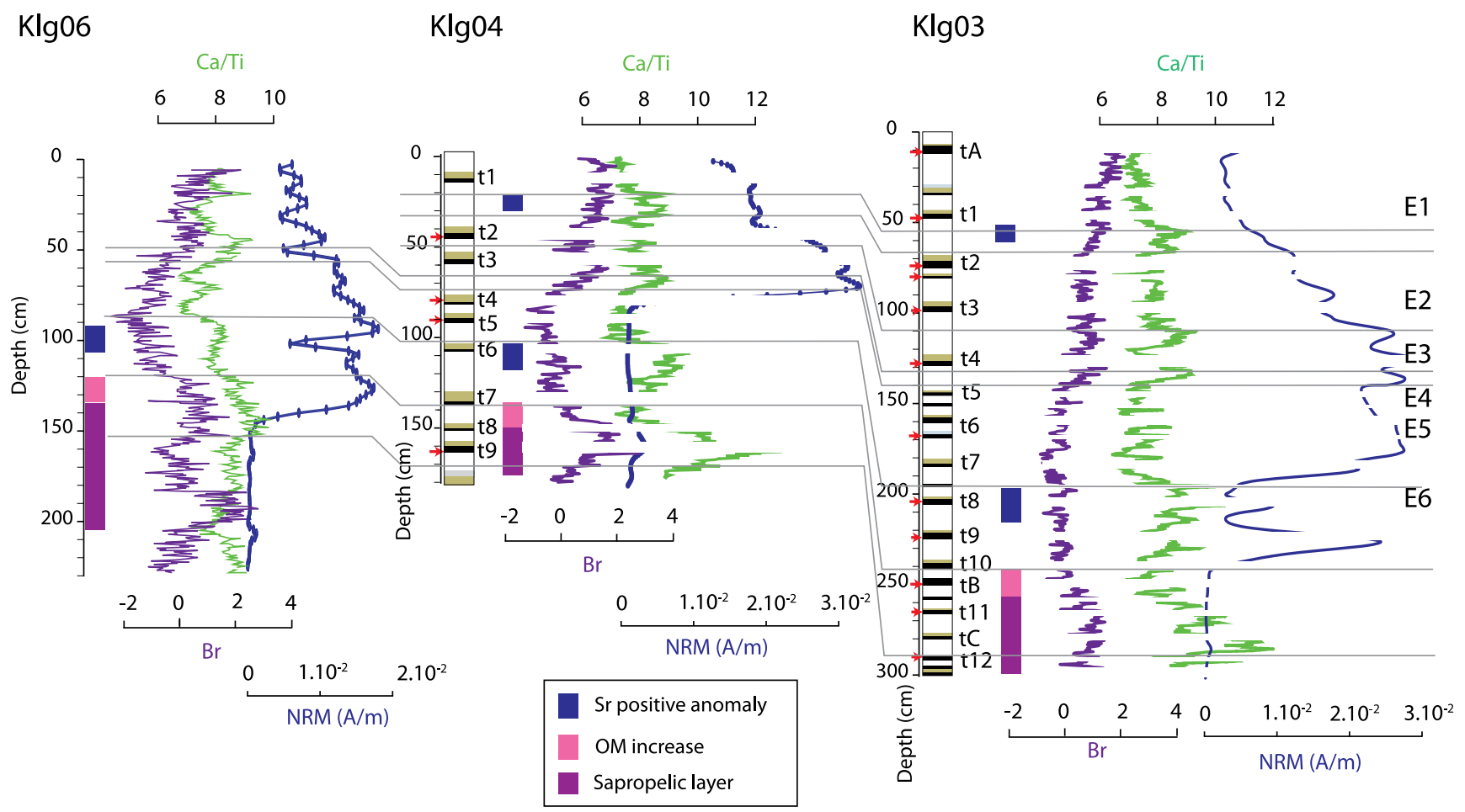

Figure 6. Correlation of cores $\mathrm{Klg} 03$, $\mathrm{Klg} 04$, and $\mathrm{Klg} 06$ according to XRF and natural remanent magnetization (NRM) measurements. NRM values decrease under the values of $1 \times 10^{-2} \mathrm{~A} / \mathrm{m}$ at $80 \mathrm{~cm}$ for $\mathrm{Klg} 04$, at $200 \mathrm{~cm}$ for $\mathrm{Klg} 03$, and $150 \mathrm{~cm}$ in $\mathrm{Klg} 06$ and are not considered reliable below these depths. The turbidite thicknesses have been deleted to solely correlate long-term environmental variations between the cores. Gray lines represent main correlation lines between the three cores. Following the correlation, turbidites that appear to occur at the same time are labeled with a capital E. The color version of this figure is available only in the electronic edition.

The different proxies are used here to define similar time horizons between the cores $\mathrm{Klg} 03$ and $\mathrm{Klg} 04$. To assess the validity of our correlation, we additionally used NRM data as a different and independent proxy for core correlation. It represents changes in magnetic carrier and in the intensity of the magnetic field. The correlation between $\mathrm{Klg} 03$ and $\mathrm{Klg} 04$ based on geochemical proxies is in agreement with the magnetic data. Also, it allows for the comparison and correlation of turbidites recorded in $\mathrm{Klg} 03$ and $\mathrm{Klg} 04$ independently of the age model derived using radiocarbon data. The correlation highlights that (1) $\mathrm{Klg} 04$ and $\mathrm{Klg} 06$ span a similar time frame (6.5 ky, according to radiocarbon data), whereas $\mathrm{Klg} 03$ records only the last $4 \mathrm{ky}$; (2) all turbidites recorded in $\mathrm{Klg} 04$ extend to $\mathrm{Klg} 03$ and are recorded at the $\mathrm{Klg} 03$ site; and (3) $\mathrm{Klg} 03$ displays more turbidites than $\mathrm{Klg} 04$ during the same time interval. The turbidites common to $\mathrm{Klg} 04$ and $\mathrm{Klg} 03$ are addressed as events marked with a capital E (Fig. 6).

Within core $\mathrm{Klg} 03$, we observed that the turbidites linked with turbidites in Klg04 always displayed sand visible to the naked eye (Fig. 6). This suggests the synchronous turbidite deposits in $\mathrm{Klg} 03$ have a proximal origin, while the others may have a distal origin. The nearest slope-failure sources are the northern slope and the shelf of the Çınarcık basin (Fig. 1c). This reasoning further leads us to identify the source of the events deposited simultaneously at the $\mathrm{Klg} 04$ and $\mathrm{Klg} 03$ sites. The $\mathrm{Klg} 04$ sediment core (1206 m.b.s.l.) is located in a berm, $35 \mathrm{~m}$ higher than the $\mathrm{Klg} 03$ site (1241 m.b.s.l.), near the base of the $1000 \mathrm{~m}$ high northern slope (Fig. 1d). Because of its particular geomorphologic location, only mass-wasting events coming from the north would be recorded at this site. On the contrary, the $\mathrm{Klg} 03$ core is located on the basin bottom in the area where the sedimentary infill is the thickest (Carton et al., 2007). Turbidite events triggered by slope destabilization from the different sides of the basin (see arrows showing masswasting paths in Fig. 1c; Altınok et al., 2011) would reach the $\mathrm{Klg} 03$ site more easily. The nonsandy Klg03 turbidites disconnected from the Klg04 ones are, in the present context, interpreted to have a far-field source located on a distal slope of the Çınarcık basin. Our study will thus focus mostly on the turbidites recorded in $\mathrm{Klg} 04$.

\section{Chronology}

Chronology of Recent Events Based on ${ }^{210} \mathrm{~Pb}_{x s}$ and ${ }^{137} \mathrm{Cs}$ Activities. The age of the turbidites in the upper $50 \mathrm{~cm}$ of $\mathrm{Klg} 03$ and $25 \mathrm{~cm}$ of $\mathrm{Klg} 04$ can be constrained using unsupported ${ }^{210} \mathrm{~Pb}$, a daughter product of radon $\left({ }^{222} \mathrm{Rn}\right)$ that diffuses as gas through the atmosphere, and ${ }^{137} \mathrm{Cs}$ data. In $\mathrm{Klg} 04$, the basal layer of turbidite $\mathrm{t} 1$ is identified at $14 \mathrm{~cm}$ (Fig. 7). The turbidite has an erosive base and shows a sharp and strong increase in grain size. $\mathrm{In} \mathrm{Klg} 03$, a turbidite with an erosive base is identified between 43 and $48 \mathrm{~cm}$ (labeled t1 in Fig. 7). Turbidite tA shows strong laminae and no erosive 


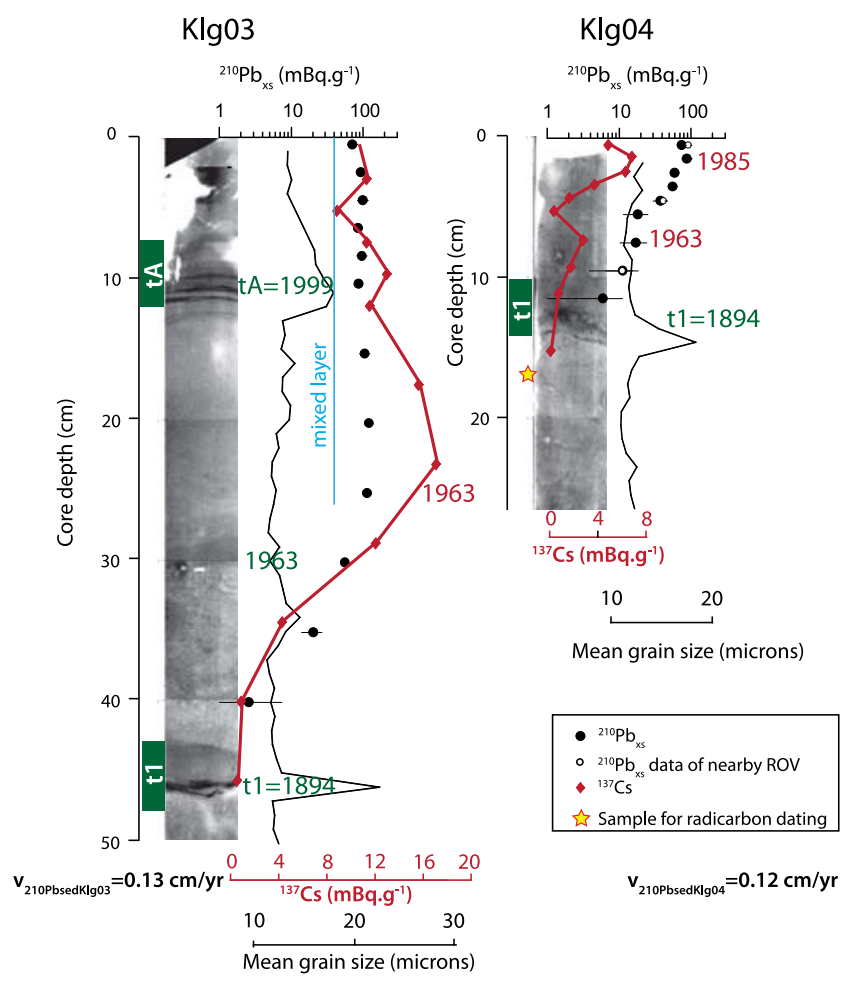

Figure 7. Excess ${ }^{210} \mathrm{~Pb}$ activities (dots), ${ }^{137} \mathrm{Cs}$ activities (diamond), and computed sedimentation rates of the cores $\mathrm{Klg} 03$ and $\mathrm{Klg} 04$. White dots along $\mathrm{Klg} 04$ are from a nearby remotely operated vehicle core and show that no significant loss of sediments occurs in the cores during coring. The extent of the mixed layer is depicted with a line in Klg03. X-ray imagery associated to the mean grain size shows the location of the turbidite likely induced by the 1894 earthquake. The turbidite is characterized by an increase in mean grain size with an erosive base for both cores. In $\mathrm{Klg} 03$, two other disturbances are also visible in the x-ray and are related with an increase in mean grain size. Turbidite tA, at $12 \mathrm{~cm}$ depth, is characterized by nonerosive laminae. Another small disturbance is observed at $30 \mathrm{~cm}$ depth without erosion. The occurrence of the peak in ${ }^{137} \mathrm{Cs}$ concentration would indicate that this turbidite is related to the $1963 M_{\mathrm{w}} 6.3$ earthquake. The color version of this figure is available only in the electronic edition.

base, along with a minor broad rise in mean grain size, a high magnetic susceptibility peak, and an increase in zirconium content (Fig. 4). Turbidite $\mathrm{t} 1$ in $\mathrm{Klg} 03$ has similar character-

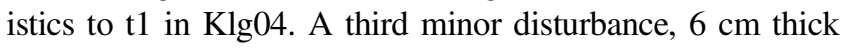
(from 29 to $35 \mathrm{~cm}$ ), is also visible in the $\mathrm{x}$-ray at $30 \mathrm{~cm}$ in $\mathrm{Klg} 03$ (Fig. 7). It is marked by sand and small Zr peaks and is mainly characterized by a disturbed clayey-silt layer.

In $\mathrm{Klg} 04$, the ${ }^{137} \mathrm{Cs}$ chronology shows a first peak at $2 \mathrm{~cm}$ depth and a second at $8 \mathrm{~cm}$. The first peak can be related to the 1986 Chernobyl event and the second to the 1963 peak in atmosphere nuclear testing (Lima et al., 2005; van Welden et al., 2008). Unsupported ${ }^{210} \mathrm{~Pb}$ is consistent with the cesium trend and exhibits, in the first $10 \mathrm{~cm}$, an exponential decay with increasing depth (black circles in Fig. 7). Radionuclide activities are also consistent with those of the nearby remotely operated vehicle short cores collected during the same cruise (UÇarkuş, 2010; white circles in Fig. 7).
We calculated the background sedimentation rate using the constant flux-constant sedimentation model (Robbins, 1978). This model assumes that the excess ${ }^{210} \mathrm{~Pb}$ in the atmosphere and in its sedimentation rate are constant through time. When these assumptions are satisfied, the ${ }^{210} \mathrm{~Pb}$ varies exponentially with depth, and a sedimentation rate can be calculated. For Klg04, the deduced background sedimentation rate is $0.12 \pm 0.01 \mathrm{~cm} / \mathrm{yr}$. By extrapolation, turbidite $\mathrm{t}$, between 10 and $14 \mathrm{~cm}$ in depth, is inferred to have occurred between 1919 C.E. and 1885 C.E., as the top of the core corresponds to 2002, the year of sampling.

In core $\mathrm{Klg} 03$, the ${ }^{137} \mathrm{Cs}$ profile shows a peak between 18 and $25 \mathrm{~cm}$, possibly related to the 1963 peak in aerial nuclear testing (Fig. 7). The uppermost $25 \mathrm{~cm}$ also displays a constant and high ${ }^{210} \mathrm{~Pb}$ activity in an inferred reworked layer. ${ }^{137} \mathrm{Cs}$ and ${ }^{210} \mathrm{~Pb}$ data imply that turbidite tA occurred very recently and may be related to the 1999 Izmit earthquake. The small disturbance detected at $30 \mathrm{~cm}$ might have been triggered by the 1963 Çinarcik earthquake. Below $25 \mathrm{~cm},{ }^{210} \mathrm{~Pb}$ activity displays a rapid exponential decay until $40 \mathrm{~cm}$, and we deduced a background sedimentation rate of $0.13 \pm 0.01 \mathrm{~cm} / \mathrm{yr}$ using the constant flux-constant sedimentation model. Low values in ${ }^{137} \mathrm{Cs}$ that would occur before aerial nuclear testing around 1954 are reached at $36 \mathrm{~cm}$. The age of turbidite $\mathrm{t} 1(43-48 \mathrm{~cm})$ was calculated using the mean sedimentation rate of $0.13 \pm 0.01 \mathrm{~cm} / \mathrm{yr}$ obtained with ${ }^{210} \mathrm{~Pb}$ from the depth of $36 \mathrm{~cm}$, corresponding approximately to the year 1954. Turbidite t1 would have been deposited between 1900 C.E. and 1862 C.E.

Radionuclide data imply that turbidite $\mathrm{t} 1$, recorded between 10 and $14 \mathrm{~cm}$ depth in Klg04 and between 43 and $48 \mathrm{~cm}$ in $\mathrm{Klg} 03$, has an age of around 1919 C.E.-1862 C.E., and thus probably has the same trigger (event E1 in Fig. 6). The 1894 C.E. $M_{\mathrm{w}} 7.3$ Prince Islands earthquake occurred at that time in the Çınarcık basin. We thus infer that this large historical earthquake triggered the event E1 in both cores.

Chronology Based on Paleomagnetic Data. Paleoinclination and paleodeclination data were obtained on both cores to provide independent age constraints. Data were only analyzed when the NRM intensities presented values greater than $1 \times 10^{-2} \mathrm{~A} / \mathrm{m}$, indicating a good preservation of the magnetic strength. This corresponded to the first $80 \mathrm{~cm}$ in $\mathrm{K} \lg 04$ and to the interval $80-190 \mathrm{~cm}$ in Klg03 (Fig. 8). The presence of turbidites implies that our record is discontinuous and affects the magnetic signal. We thus removed data from all the sandy bases of the turbidites considered to be unreliable due to strong grain size variation. We then calculated a mean value for the silt and clay layers. These average values were interpreted to represent paleoinclination and paleodeclination at the time of, and just after, turbidite deposition, respectively. Finally, all of the data were kept for the hemipelagic sedimentation.

The paleoinclination and paleodeclination data were compared with the reference curve of secular variation in inclination and declination computed at the latitude of the coring 

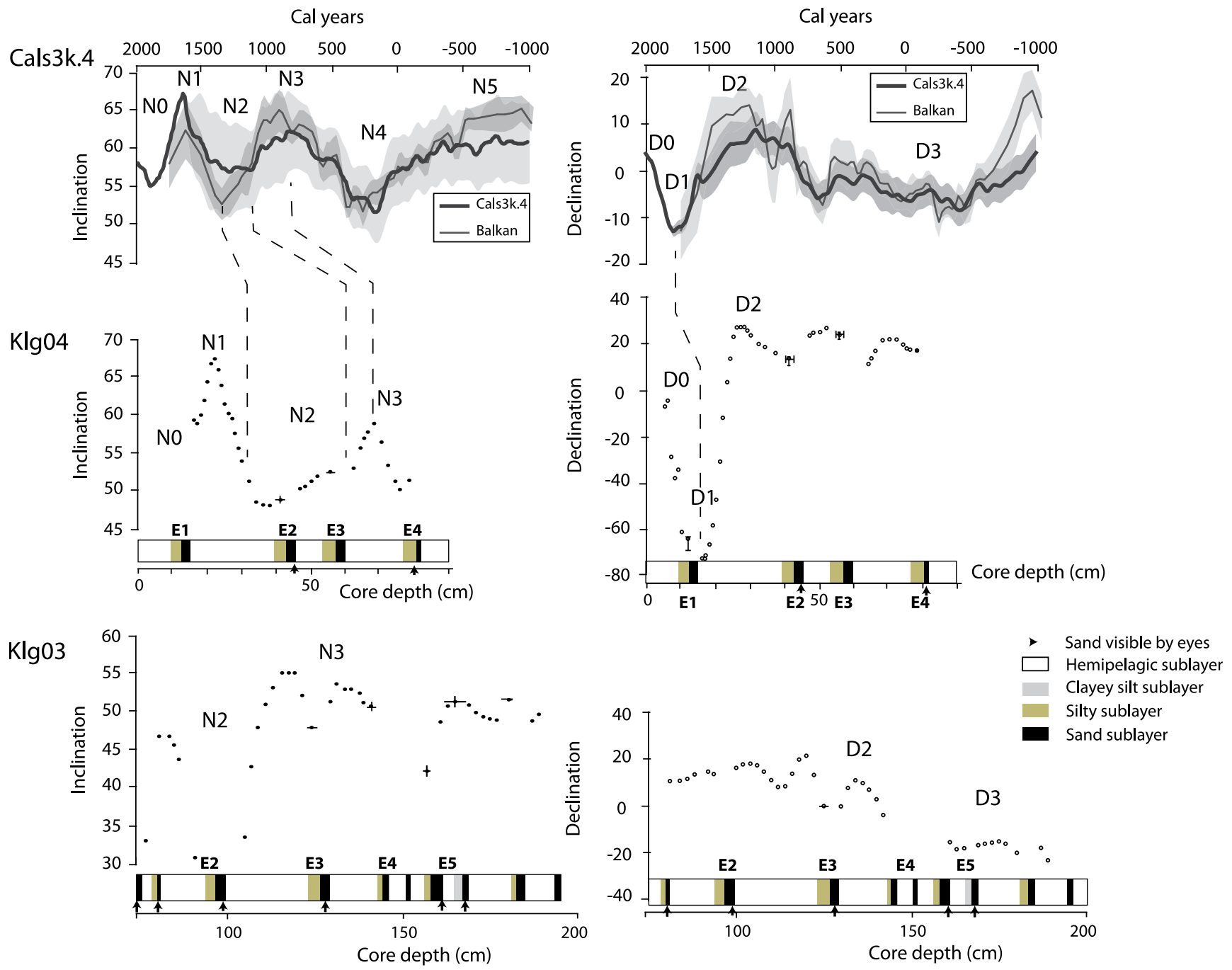

Figure 8. Cals3k.4 (see Data and Resources) and Balkan reference curves for paleoinclination and paleodeclination are compared with the paleoinclination and paleodeclination records of $\mathrm{Klg} 04$ and $\mathrm{Klg} 03$. All sand bases of the turbidites have been removed. The means of paleoinclination and paleodeclination data were obtained for the silt layer, whereas all data were kept for hemipelagic sediments. The models show characteristic trends with periods of low and high inclination. The same trends are observed for cores Klg04 and Klg03. Black lines represent standard deviation calculated for silt and hemipelagic layers. The color version of this figure is available only in the electronic edition.

site for the last 2000 years (Korte and Constable, 2011) and with a local curve obtained in the Balkans (Tema and Kondopoulou, 2011) (Fig. 8). We focused mostly on core $\mathrm{Klg} 04$, which has a more robust data set than $\mathrm{Klg} 03$. The $\mathrm{Klg} 03$ record is also included as it shows a secular variation of geomagnetic field similar to $\mathrm{K} \lg 04$ and because the dataset covers a longer time frame than $\mathrm{Klg} 04$. Therefore, it provides additional time constraints. The fact that the Klg04 record and the reference curves present correlatable patterns in inclination and declination supports the reliability of the record.

The Klg04 mean inclination is close to expected values $\left(54^{\circ}\right)$, and magnetic inclination minima and maxima can be identified. The Klg04 mean inclination presents similar variations to the reference models for the last 2000 years, with corresponding periods of low and high inclination. A direct comparison of the relative ChRM inclination of core $\mathrm{Klg} 04$ and the computed inclination from the model allows for the deter- mination of four common paleomagnetic inclination features (N0, N1, N2, and N3 in Fig. 8). Events E2 and E3 occurred during the low inclination period N2 (between about 1600 and 1100 cal years), and event E4 occurred at the end of the high inclination values of the $\mathrm{N} 3$ period (about 500 cal years).

Declination in Klg04 exhibits the same trends as the reference curve, and three periods with identical trends can be identified (D0, D1, and D2). Events E2 and E3 were deposited during the period D2, between 1600 and $1000 \mathrm{cal}$ years, whereas event E4 occurred before the large decrease in declination around 800 cal years, suggesting that this turbidite may have been deposited between 1000 and $800 \mathrm{cal}$ years. Four turbidites are thus recorded in about $1000 \mathrm{cal}$ years. This result was used as a chronological marker to derive the reservoir age for the Çınarcık basin.

The Klg03 and Klg04 records present a similar pattern in inclination and declination, even if the inclination in 
$\mathrm{Klg} 03$ is shallower, indicating a possible tectonic disturbance or a mechanism of inclination shallowing (Tauxe and Kent, 1984). The comparison with the reference models allows for the match of paleomagnetic changes between core $\mathrm{Klg} 03$ and the reference curves, as we have done for $\mathrm{Klg} 04$. $\mathrm{Klg} 03$ records inclination periods $\mathrm{N} 2$ and $\mathrm{N} 3$, but the record is not reliable enough to interpret inclination data further. In addition, $\mathrm{Klg} 03$ records declination periods D2 and D3 (Fig. 8). Event E4 occurred during the high inclination period N3 (1100-500 cal years); event E5 occurred at the top of the low declination period D3 (between 500 and -500 cal years). This suggests that E5 was deposited before 500 C.E.

Chronology of Seismoturbidites Based on Radiocarbon Data. Obtaining an age model is complicated in marine environments because of the presence of a radiocarbon-depleted signal within the oceans (Siani et al., 2001; Reimer and McCormac, 2002). Indeed, the ocean is a large carbon reservoir and has a longer residence time for ${ }^{14} \mathrm{C}$ than the atmosphere. Radiocarbon ages obtained from marine shells thus have an apparent age older than atmospheric samples. The marine reservoir age is defined as the difference between ${ }^{14} \mathrm{C}$ samples from marine and terrestrial material of the same age (Stuiver et al., 1986) and is composed of a global reservoir correction $R$ (about 400 years) and a local deviation $(\Delta R)$ that can be as large as 1000 years (Stuiver et al., 1986). To obtain an accurate chronology in a marine environment, the key issue is thus to assess the right reservoir age. The only data pertaining to the Marmara Sea were obtained by McHugh et al. (2006). The authors constrained the ${ }^{14} \mathrm{C}$ ages of modern prebomb marine mollusk shells of the Marmara Sea and calculated a total average age reservoir of $460 \pm 40 \mathrm{yr}(\Delta R=71 \mathrm{yr})$ and $340 \pm 40 \mathrm{yr}(\Delta R=91 \mathrm{yr})$, following Siani et al. (2000).

The combination of radionuclide and paleomagnetic data with radiocarbon ages suggests that a much larger marine reservoir correction is needed. Indeed, radionuclide dating suggests that the turbidite E1 was deposited between 1919 C.E. and 1862 C.E. The radiocarbon age of the foraminifera sample (1060 $\pm 30 \mathrm{yr}$ B.P. at $17 \mathrm{~cm}$ in Klg04) just below event E1 implies a large reservoir age of about 900 years (Table 3). Moreover, the variations in declination and inclination imply that the first $70 \mathrm{~cm}$ of the core Klg04 spans about 1000 years (Fig. 8), while the uncalibrated radiocarbon age at $68.5 \mathrm{~cm}$ in $\mathrm{Klg} 04$ is $1740 \pm 35$ years. Therefore, we estimated a total reservoir age of 800-900 years for the Marmara Sea and applied a local reservoir deviation $(\Delta R)$ of $400 \pm 50$ year to the marine calibration curves in OxCal. Possible variations in reservoir age overtime were ignored because of lack of data to address this problem (Goldfinger et al., 2012).

To determine the age of turbidite deposits, we used an OxCal model with nonrounded ages (Reimer et al., 2013). The software derives modeled probability density functions of the samples and sedimentary events (Fig. 9). The modeled ages were based on the P_Sequence depositional model, which allows random variation from an approximately constant sedimentation rate (Bronk Ramsey, 2007). Boundaries were applied as in Kagan et al. (2010) when a major change in sedimentation was suspected. The top boundary of the model is constrained by the age of the 1894 earthquake, which radionuclide measurements imply corresponds to event E1. Time constraints were also applied using the top of the upper sapropelic layer and the secular variation of the magnetic field (as a C_Date). Finally, the age-depth model is presented based on the $95 \%$ confidence interval of the modeled ages (the gray polygons downcore in Fig. 9).

A first ${ }^{14} \mathrm{C}$-based age model was constructed using only constraints from core Klg04 (Fig. 9a). A second model was then obtained by applying radiocarbon and paleomagnetic data from core $\mathrm{Klg} 03$ to core $\mathrm{Klg} 04$ based on the correlation presented in Figure 6. Eight samples (Klg04, $45.5 \mathrm{~cm}$; $\mathrm{Klg} 04,91 \mathrm{~cm}$; Klg04,162 cm; Klg04, 184 cm; Klg04, 197; $\mathrm{Klg} 04,214 \mathrm{~cm}$; Klg03, $88 \mathrm{~cm}$; and Klg03-plc-114 cm) largely overestimated the expected age of the host sediment. These samples were regarded as being reworked and were not used in the model (indicated in italics in Table 2). Samples extracted from the sandy base of the turbidites (Klg04, $38 \mathrm{~cm}$; Klg04, $59 \mathrm{~cm}$; Klg03, $98 \mathrm{~cm}$; Klg03, $203.5 \mathrm{~cm}$; and $\mathrm{Klg} 03,245 \mathrm{~cm}$ ) were assumed to be reworked material incorporated into the mass flow. They are considered to predate the turbidite deposit and were incorporated below the turbidites in the model. Finally, 16 radiocarbon samples were used to make an order-constrained Bayesian model using the OxCal software (Reimer et al., 2013).

The results are presented with $95 \%$ age probability in Figure 9. In the first model, events E2, E3, and E4 have calendar age ranges of 1322-1474 C.E., 1201-1341 C.E., and 734-1014 C.E., respectively. The OxCal model also constrains the age range of the four other events at 520-856 C.E. (E5), 2-488 C.E. (E6), 748-407 B.C.E. (E7), and 955-593 B.C.E. (E8). In the model comprising data from $\mathrm{Klg} 03$, events have similar age ranges. Events E2, E3, and E4 have 95\% confidence interval calendar age ranges of 1364-1511 C.E., 1268-1360 C.E., and 779-1041 C.E., respectively. The OxCal model also constrains the age range of the four other events at 607-867 C.E. (E5), 136-481 C.E. (E6), 771-522 B.C.E. (E7), and 1090-890 B.C.E. (E8). The order-constrained Bayesian model was also used to determine an average recurrence interval of 256-321 years for turbidites synchronous at both sites. This average recurrence interval is in agreement with the recurrence interval that can be calculated from inclination data (250 years).

\section{Discussion}

Timing and Causes of Changes in Sedimentation Rates

Comparing turbidite-free sediment accumulation through time at the two sites provides some insights about major changes in sedimentation rates in the Çınarcık basin over 
(a)

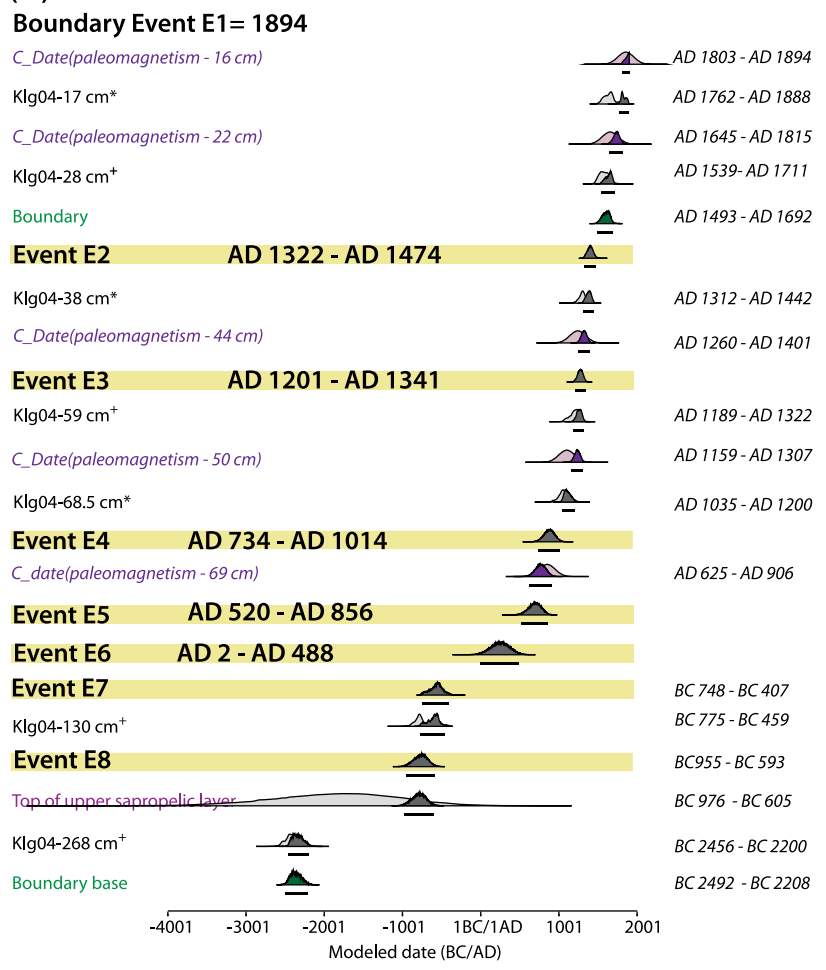

\begin{tabular}{|ll|}
\hline * & Benthic foraminifers (Bullumina Marginata d'Orbigny) \\
\# & Planktonic foraminifers (G. Bulloides) \\
+ & Shells samples (phylum mollusca monoplacophara) \\
\hline
\end{tabular} (b)

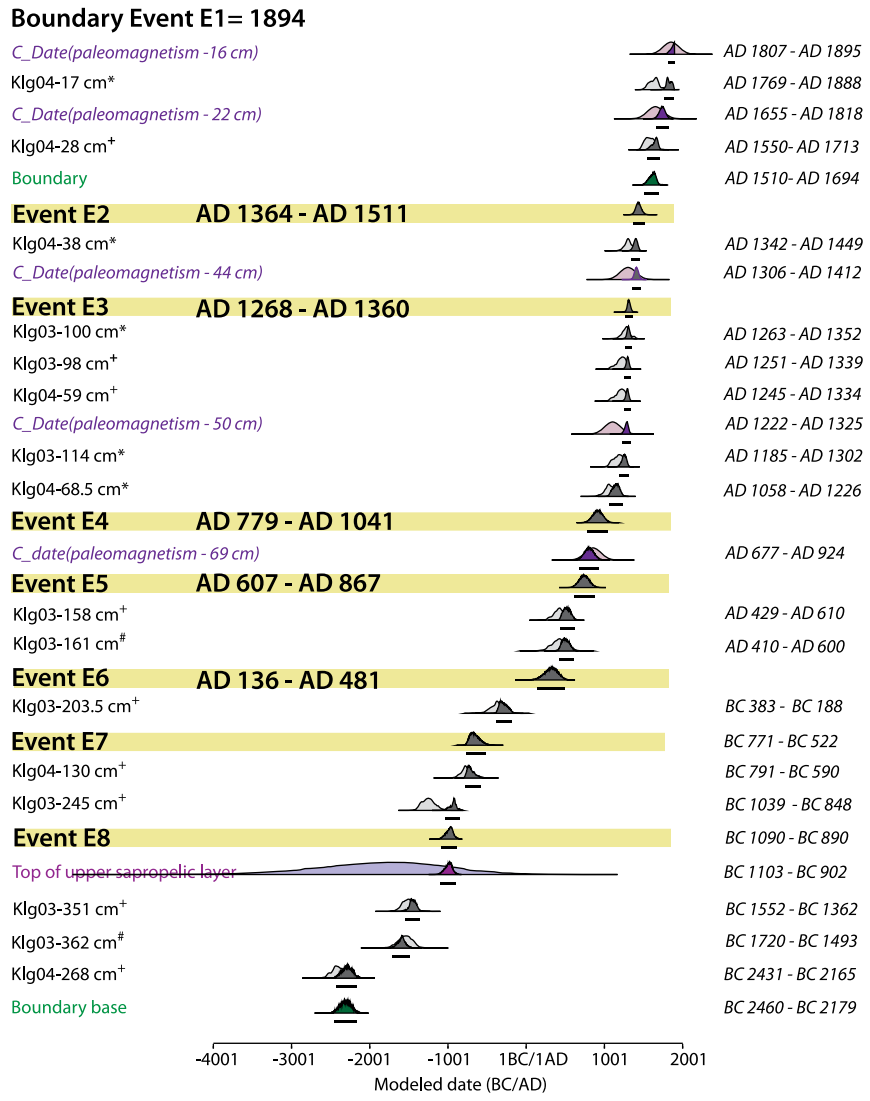

Figure 9. A chronological model built using OxCal software (Bronk Ramsey, 2007) for a $\Delta R$ of $400 \pm 50$ years with event E1 (1894 earthquake) put as the initial boundary for the calibration. Data are arranged in stratigraphic order and turbidites age-modeled distributions are highlighted. Corresponding sample numbers are adjacent to each distribution (probability density functions) in which black lines correspond to the $95 \%$ confidence interval. The model on the left side of (a) considers radiocarbon data only coming from the Klg04, whereas the model on the right of (b) uses the radiocarbon constraints from core Klg03. The color version of this figure is available only in the electronic edition.

the last 4000 years. Despite the differences in the turbidite occurrences, the two cores have similar accumulation rate curves and show identical major changes in sedimentation pattern (Fig. 10). Five periods with different sedimentation rates are recorded. The chronology allows for the discussion on their origins.

An anomaly occurred in the $110-165 \mathrm{~cm}$ interval in $\mathrm{Klg} 04$ and below the depth of $170 \mathrm{~cm}$ in Klg03. During this period, labeled $\mathrm{P} 4$, sedimentation rates are similar at the $\mathrm{Klg} 03$ and $\mathrm{Klg} 04$ sites, but they are high $(0.08 \mathrm{~cm} / \mathrm{yr}$ in $\mathrm{Klg} 04$ and $0.14 \mathrm{~cm} / \mathrm{yr}$ in $\mathrm{Klg} 03$ ). In the OxCal model, the P4 period occurred between 900 B.C.E. and 1600 B.C.E. and is coincident with the occurrence of the upper sapropelic layer referenced between 4.75 and 3.2 ky B.P. by Çağatay et al. (1999) in the Marmara Sea. Sapropelic layers are characterized by good preservation of the organic material in a reductive environment (Cramp and O'Sullivan, 1999). One way that sapropels are formed involves the slowing down of oxygen flux in the sediment, and the most effective process to reduce bottom water ventilation is to have a high sediment influx (Calvert, 1990; Çağatay et al., 2004). The high sedimentation rate during this period could also be related to the beginning of forest clearance and crop agriculture in the Marmara watersheds, starting at 1450 B.C.E. years (Eastwood et al., 1998; Leroy et al., 2002); indeed a peak in sedimentation rate is documented in lakes and along the southern shelf of the Marmara Sea at that time (Kazanci et al., 2004).

However, during the $\mathrm{P} 4$ period, about five turbidites are recorded in $\mathrm{Klg} 04$, which would imply a recurrence rate of earthquakes of about 75 years. Such a high recurrence rate is improbable, and we suspect that the reservoir age determined for the upper part of the cores is invalid during P4, perhaps because the stratification of the water body at the time of deposition of the sapropelic layer was different from the present one (Reimer and McCormac, 2002).

The $\mathrm{P} 3$ period is marked by a sedimentation rate at the $\mathrm{Klg} 04$ site that is half the rate at the $\mathrm{Klg} 03$ site. In addition, turbidite deposits are more frequent at the $\mathrm{Klg} 03$ site than at the $\mathrm{Klg} 04$ site. These differences might be directly linked to the fact that less sediment was available during that time on the northern shelf and slopes than on the southern ones. 
(a)

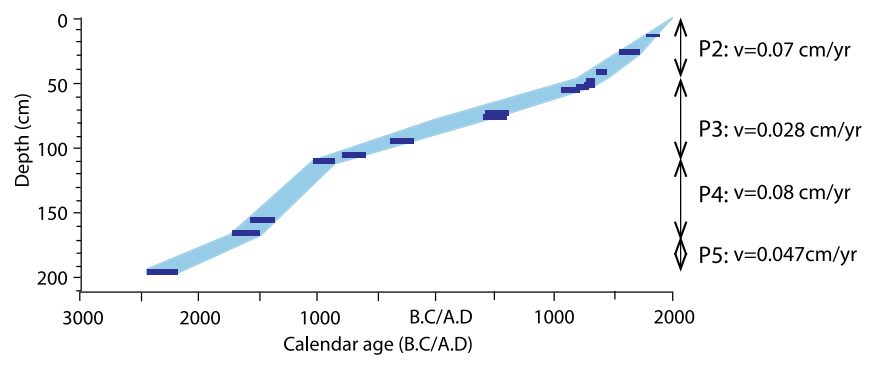

(b)

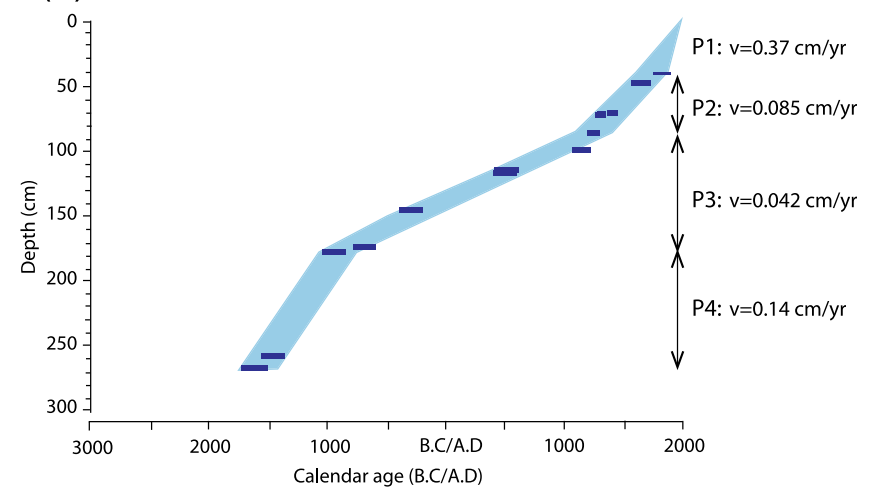

Figure 10. Sediment-accumulation-rate curves in a turbidite-free scale for (a) Klg04 and (b) Klg03. The core correlation (Fig. 6) allows for the transfer of ${ }^{14} \mathrm{C}$ ages from one core to the other. Sedimentation rate, $\mathrm{v}$, for the different periods are indicated for both cores to the right of the curves. The color version of this figure is available only in the electronic edition.

The $\mathrm{P} 2$ period is marked by a slight increase in sedimentation rate in $\mathrm{Klg} 03$ and in $\mathrm{Klg} 04$ in comparison with the $\mathrm{P} 3$ period. The P3-P2 transition corresponds to a decrease in clay content and to an increase in silt recorded in all of the cores in the Marmara Sea (Figs. 4 and 5, and Drab et al., 2012). It implies that sediment input to the Marmara northern margin was increasing even if watersheds around Istanbul were restricted and could not have been an important sediment sources (i.e., most of the sediment yield comes from rivers from the southern margin of the Marmara Sea; Smith et al., 1995). This increase in sedimentation rate might be a consequence of the intensification of soil erosion and of agricultural development around Istanbul. This event might be related to the renewed development of Constantinople during the Ottoman period after 1453.

The most recent change in sedimentation rate is observed in $\mathrm{Klg} 03$ after 1894 . The sedimentation rate increased to about $0.37 \mathrm{~cm} / \mathrm{yr}$ due to the deposition of turbidite tA. This value is close to rates obtained during the twentieth century in lakes located on the southern part of the Marmara Sea and from sediment sampled from the Kocasu River, one of the major sediment sources for the Marmara Sea, and is characteristic of poor land use and deforestation (Kazanci et al., 2004). We interpret the increase in sedimentation rate occurring at the $\mathrm{Klg} 03$ site as linked to a marked increase in sediment input on the Marmara southern shelf and slopes. The latter might be related to the dramatic shift in agricultural practices over the past century involving the replacement of working animals with machines. Because of the increase of sediment yield, mass failure related to far-field earthquakes can occur as with the 1999 earthquake recorded in the Çınarcık basin (Fig. 7).

\section{Triggers of Turbidites Documented in $\mathrm{Klg} 03$ and} $\mathrm{K} \lg 04$

Considering the specific geomorphic setting of the Çınarcık basin and the core locations (McHugh et al., 2006; Sarı and Çağatay, 2006), storms, earthquakes, and/or sediment loading are the only possible triggering mechanisms for turbidites in Klg03 and Klg04. Four distinct arguments lead us to consider that turbidites deposited in the studied cores are seismically generated.

First, in the Marmara Sea, the distance a given wind can blow over the water is very restricted; thus whatever the storm, the wave height is restricted, as is the related wave energy. So storms in this particular setting are unlikely to trigger turbidites. Second, slope failure linked only to sediment loading on the northern slope of the Çinarcik basin is questionable. The faulted margin of the basin in the vicinity of the Klg03 and $\mathrm{K} \lg 04$ cores is too steep to accumulate a significant sedimentary load (Çağatay et al., 2012). In addition, sediment input on the northern shelf is restricted due to the very small watersheds draining the land to the north of the Çınarcık basin. Cumulative Holocene sedimentation reaches a maximum of $2.5 \mathrm{~m}$ in the middle of the shelf and less than $1 \mathrm{~m}$ in its southern part (Çağatay et al., 2009). Excess sedimentary loading on the edge of the shelf is thus unlikely.

Third, the turbidites we identified in $\mathrm{Klg} 03$ and $\mathrm{Klg} 04$ have sedimentological characteristics identical to the specific properties of earthquake-triggered turbidites in the Marmara Sea and the Izmit Gulf studied by others (McHugh et al., 2006; Sarı and Çağatay, 2006; Beck et al., 2007; Çağatay et al., 2012; Drab et al., 2012) (see the Seismoturbidite Characteristics section). Such multiple sources in a turbidite deposit are linked to a series of catastrophic failures and turbidite currents triggered within perhaps minutes of each other (Goldfinger et al., 2012). Such a phenomenon can uniquely be generated by earthquake shaking in the Marmara setting. Finally, another test to determine if turbidites are seismically generated is to check the synchronicity of the documented events regionally (McCalpin, 1996; Goldfinger, 2011; Goldfinger et al., 2012). Our test rests upon the time correlation obtained to the dated reference core, Klg06, located in a different structural setting. Figure 6 shows that the turbidites in the $\mathrm{Klg} 04$ core are systematically correlated to ones in $\mathrm{Klg} 03$. The $\mathrm{Klg} 03$ and $\mathrm{Klg} 04$ cores are, however, only separated by $3 \mathrm{~km}$, which might not be distant enough 
to completely fulfill this synchronicity test. We thus looked at the C15 core (Sarı and Çağatay, 2006) located several kilometers from Klg03 (Fig. 1c). Sarı and Çağatay (2006) documented quartz-rich seismoturbidites at 61 and $74 \mathrm{~cm}$ with uncalibrated ages of $1470 \pm 35 \mathrm{yr}$ B.P. and $1890 \pm 35 \mathrm{yr}$ B.P. Independently of any age reservoir correction, the radiocarbon ages imply that the two turbidites correlate with events E2 and E3 in Klg04 (Fig. A2).

Based on their sedimentological characteristics, large lateral extent, and synchronicity, we conclude the turbidites deposited simultaneously in $\mathrm{Klg} 03$ and $\mathrm{Klg} 04$ are earthquake triggered. The original mass failure would come from the Çınarcık northern slope (see the Correlation of Cores and Turbidites section) and must be related to rupture of the fault running at the slope base. We thus infer that these seismoturbidites have been triggered by large earthquakes along the northern Çinarcık fault segment.

The Klg03 site is located on the Çınarck basin floor, where seismoturbidites from different sources can be deposited. The basin is bounded to the north and south by the Çınarcik segment and the southern segment, respectively; to the west by the Central segment crossing the Central High; and to the east by the Izmit segment (Fig. 1b). An $M_{\mathrm{w}}>7$ earthquake along one of these faults would destabilize broad parts of the bounding slopes and initiate a huge volume of sediment flows. Turbidites can travel considerable distances across flat basin floors. We speculate the turbidites present in $\mathrm{Klg} 03$ (but not in Klg04) may have a seismic trigger but with a far-field origin. The seismicity in the region is so high that earthquakes are the most likely trigger for slope failure. Indeed, the first turbidite recorded in $\mathrm{Klg} 03$, labeled tA, occurred very recently according to radionuclide data and can be attributed to the $1999 M_{\mathrm{w}} 7.4$ earthquake (Fig. 7). A similar far-field turbidite was triggered in the Black Sea approximately at the same distance as the Çınarcık basin (Yücel et al., 2010). The event has a particular sedimentological imprint with a nonerosive base associated with an increase in magnetic susceptibility and grain size.

\section{Inferred Rupture History for the Çınarcık Segment and Adjacent Segments}

The turbidite record deposited in a minor push-up structure along the Çınarcık fault places some new constraints regarding past ruptures of the Çinarcık fault. In the following section, we combine the historical catalog with the proposed age model to reconstruct an history of ruptures along the Çınarcık fault. We infer the historical catalog for large magnitude earthquakes has been complete since Istanbul was founded to become the capital of the Roman Empire in 324 C.E. (Gibbon, 1829). The earthquake record represented in Figure 1 shows that a wealth of large earthquakes has been inferred to have occurred in the Çinarcık basin. However, it is not possible to know exactly which one ruptured the Çınarcık fault. In the following section, we will compare the history of ruptures of the Çınarcık fault with historical records. From the combination of the present dataset and paleoseismological record, a coherent history of ruptures can be reconstructed.

The radionuclide data implies that turbidite E1 would occur between 1919 C.E. and 1885 C.E. The $1894 M_{\mathrm{w}} 7.3$ earthquake (Ambraseys, 2002) affected a large area from Istanbul to Izmit (see isointensity curves from Eginitis, 1894, and in Ince, 2011). Ambraseys (2002) located the earthquake epicenter in the east of the Marmara Sea near the Hersek Peninsula. A significant tsunami in Bosphorus and Prince Islands (Yalçıner et al., 2002; Altınok et al., 2011) was associated with this earthquake. Using a modeling approach for the tsunami, Hebert et al. (2005) concluded the 1894 earthquake source must have extended in the Çınarcık basin, likely with a normal component. Pondard et al. (2007), using Coulomb stress failure modeling, also deduced that the 1894 earthquake broke the northern- or southern-bounding fault of the Çınarcık basin. Klg03 and Klg04 both record the 1894 earthquake, implying that the northern Çınarcik fault ruptured.

The magnetic chronomarkers point out that the three previous turbidite events, E2, E3, and E4, occurred between 1500 and 900 cal years (Fig. 8). In addition, the OxCal chronology (Fig. 9, Table 3) strongly suggests these events are related to $M_{\mathrm{w}}>6.8$ earthquakes occurring in 1509 C.E., during the fourteenth century (1296 C.E., 1353 C.E., 1344 C.E., or 1343 C.E.) and in 989 C.E. The 1509 C.E. earthquake caused heavy damages on both sides of Istanbul implying an epicenter location at the boundary between the Çınarcık and the Central faults (Ambraseys, 2002). The earthquake triggered a large tsunami (6 m runup; Ambraseys and Finkel, 1991; Yalçıner et al., 2002), attributed to the rupture of the Çınarcık fault (Hebert et al., 2005). Our records are compatible with this scenario. Paleoseismic data further east also suggest an NAF rupture at that time, with the most recent surface rupture across the Hersek delta (Kozaci et al., 2010, 2011) attributed to the 1509 C.E. earthquake. The earthquake rupture is confirmed further east in paleoseismic trenches (Klinger et al., 2003) and recorded in cores just west of Hersek (McHugh et al., 2006), in the Hersek Lagoon (Bertrand et al., 2011), and in the Karamusel Bay (Çağatay et al., 2012). The inferred $100 \mathrm{~km}$ long rupture would be compatible with the $70 \pm 30 \mathrm{~km}$ long rupture estimated in Ambraseys (2001).

During the thirteenth and fourteenth centuries, there was a sequence of earthquakes (sequence 2 in Fig. 11) in the Marmara region: in 1296 C.E. $\left(M_{\mathrm{s}} 7\right), 1343$ C.E. $\left(M_{\mathrm{s}} 7\right), 1344$ C.E. $\left(M_{\mathrm{S}} 6.9\right)$, and 1354 C.E. $\left(M_{\mathrm{s}} 7.4\right)$. None of these earthquakes were located in the Çinarcik basin by Ambraseys (2002). However, historical reports from that period are less reliable because the Roman Empire was struggling to survive (Gibbon, 1829). Indeed, Istanbul was taken and sacked by the Crusaders in 1203 C.E. In 1261 C.E., the Emperor took the city back, but the population was about 35,000 people. Then, in 1347 C.E., Istanbul was hit by the plague; and, when the Ottoman Turks captured the city in 1453 C.E., it contained approximately 50,000 people. The 1296 C.E. earthquake occurred in the east of the Çınarcık basin (Ambraseys, 2002) and was documented in the Karamusel basin (Çağatay et al., 2012). The 1343 C.E. 
and 1354 C.E. earthquakes occurred in the western part of the Marmara Sea and were confirmed in paleoseismic trenches (Rockwell et al., 2001, 2009; Meghraoui et al., 2012). McHugh et al. (2006) documented a seismoturbidite in the Central basin attributed to the 1343 C.E. earthquake. Based on historical sources, the 1344 C.E. earthquake has been located in the central part of the Marmara Sea (Ambraseys, 2002). It was associated with a tsunami that caused significant damage in Istanbul and inundated the Bosphorus, reaching up to $2000 \mathrm{~m}$ (Altınok et al., 2011). A $1.2 \mathrm{~m}$ tectonic uplift of the Hersek Peninsula (Özaksoy et al., 2010) also occurred during that time period. Finally, we documented one of these events in our cores. Therefore, we conclude the 1344 C.E. earthquake ruptured the Çinarcik fault, as it is the only event that triggered a tsunami in Istanbul (Hebert et al., 2005). In that case, the 1354 C.E. and 1343 C.E. earthquakes would have occurred on the Central-Tekirdağ-Ganos faults and the 1296 C.E. earthquake on the Izmit fault.

The next large historical earthquake is the 989 C.E. $M_{\mathrm{w}} 7.2$ earthquake located in the Çınarcık basin (Ambraseys, 2002). The earthquake was associated with a damaging tsunami in Istanbul (Altınok et al., 2011) and was also recorded in the Hersek Lagoon (Bertrand et al., 2011), but not in the Karamusel basin (Çağatay et al., 2012). Because we record a turbidite at that time (E4), we conclude that the 989 C.E. earthquake ruptured the Çınarcık fault and may have extended to the Hersek Peninsula.

Event E5 is dated between 607 C.E. and 867 C.E. The largest earthquake within this age range is the 740 C.E. $M_{\mathrm{w}} 7.1$ earthquake. Ambraseys (2002) located the epicenter of this earthquake in the Çınarcık basin. The earthquake was associated with (1) a large tsunami (Altınok et al., 2011) affecting Istanbul in the Izmit area and (2) an atypical subsidence in the Hersek Peninsula of about $2 \mathrm{~m}$ (Bertrand et al., 2011). This earthquake was also documented in the Central basin (McHugh et al., 2006) and in the Izmit Bay (Çağatay et al., 2012). We thus conclude that the 740 C.E. earthquake may have ruptured the Çınarcık fault.

Event E6 occurred between 136 C.E. and 481 C.E. According to historical reports, Ambraseys (2002) located two earthquakes during that time lag (the 407 C.E. $M_{\mathrm{w}} 6.6$ and the 437 C.E. $M_{\mathrm{w}}$ 6.8), and Guidoboni and Comastri, (2005) also locate the 447 C.E. $M_{\mathrm{w}} 7.2$ and 478 C.E. $M_{\mathrm{w}} 7.3$ earthquake in the Istanbul area. Only the 407 C.E., 447 C.E., and 478 C.E. earthquakes were associated with a tsunami invading Istanbul (Altınok et al., 2011). According to historical reports, the 478 C.E. earthquake was associated with a stronger tsunami. E6 may be related to one of these earthquakes and perhaps more likely with the 478 C.E. $M_{\mathrm{w}} 7.3$ earthquake. It is also consistent with the average recurrence interval calculated for the segment. Nevertheless, the lack of information from other studies does not allow us to further discuss the location of this earthquake.

Older turbidite events have limited time constraints, and the earthquake catalog may not be complete. Before 324 C.E., the largest town in the area was Nicomedia (i.e., Izmit).
The city was located on the NAF segment, lying just east of the Çınarcık fault. A large earthquake on the Çınarcık fault would also have impacted the city and might be recorded in the historical catalog. The Oxcal model shows that about 1000 years separate event E6 from event E7, which implies that the reservoir age in the Marmara Sea might have changed between those two events. Therefore, we cannot constrain the interpretation any further.

Finally, we do not record any turbidites in the site along the Çınarcik fault in the eighteenth century. During that time period, a westward-propagating earthquake sequence (labeled sequence 3 in Fig. 11) consisted of four strong shocks in 1719 C.E., 1754 C.E., May 1766 C.E., and August 1766 C.E. The 1719 C.E. $M_{\mathrm{w}} 7.4$ and the 1754 C.E. $M_{\mathrm{w}} 6.8$ earthquakes occurred in the eastern part of the Marmara Sea (Ambraseys, 2002). There is widespread evidence of an eighteenth century earthquake in paleoseismic trenches along the 1999 Düzce and Izmit earthquake ruptures (Rockwell et al., 2001, 2009; Sugai et al., 2001; Klinger et al., 2003; Fraser et al., 2010), but it is not possible to determine exactly which earthquake occurred at a particular spot within this time window. The August 1766 C.E. earthquake occurred in the western part of the Marmara Sea, and paleoseismic trenches west of the Marmara Sea also reveal surface ruptures attributed to the 1659 C.E. $\left(M_{\mathrm{s}} 7.2\right)$ or to the August 1766 C.E. $\left(M_{\mathrm{s}} 7.4\right)$ earthquakes (Rockwell et al., 2009; Meghraoui et al., 2012). The location of the May 1766 C.E. $M_{\mathrm{w}} 7.1$ earthquake is strongly debated, with Ambraseys (2002) inferring a location in the Çınarckk basin and others (Pondard et al., 2007) in the Central basin. The triggered tsunami induced damage in the Bosphorus (Yalçıner et al., 2002) and suggests a rupture in the Çınarcık basin (Hebert et al., 2005). There are no apparent turbidites recorded during that period along the Çınarcık fault, but a turbidite is recorded at the Klg03 site (Fig. 6, t2). Furthermore, Drab et al. (2012) documented seismoturbidites, probably related to the May and August 1766 C.E. earthquakes, in the Tekirdağ and Central basins. In addition, there is no surface rupture across the Hersek delta during that period (Kozaci et al., 2010, 2011), and the sediment record in the Karamusel basin (Çağatay et al., 2012) contains no distinctive identifying signal of these earthquakes.

We thus propose the two following scenarios: (1) the 1719 C.E. and 1754 C.E. earthquakes occurred east of the Hersek Peninsula, the May 1766 C.E. earthquake broke the Central fault, and the 1659 C.E. and August 1766 C.E. earthquakes ruptured the Ganos and Tekirdağ faults. This scenario is still compatible with earthquake damages (Ambraseys, 2002). (2) However, it is not possible to exclude that the May 1766 C.E. ruptured a fault along the southern edge of the Çınarcık basin, a scenario more compatible with Coulomb stress analysis of Pondard et al. (2007). In that case, the 1696 C.E. earthquake would be similar to the 1912 earthquake, rupturing the Ganos and Tekirdağ segments, and the August 1766 C.E. would have ruptured the Central fault.

Since the ninth century, three complete sequences have released stresses along the NAF (Fig. 11). The present seismic cycle is incomplete, with a seismic gap along the Central fault 


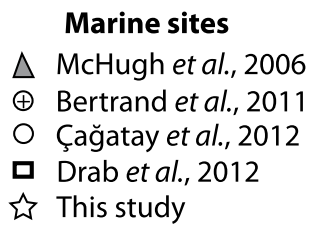

\section{Land sites}

$\triangle$ Klinger et al., 2003

口 Rockwell et al., 2009

- Leroy et al., 2010

O Kozaci et al., 2011

$\diamond$ Meghraoui et al., 2012
From West to East Ganos Segment

- - Tekirdağ Segment Central Segment Çınarcık Segment Southern Segment Izmit Segment

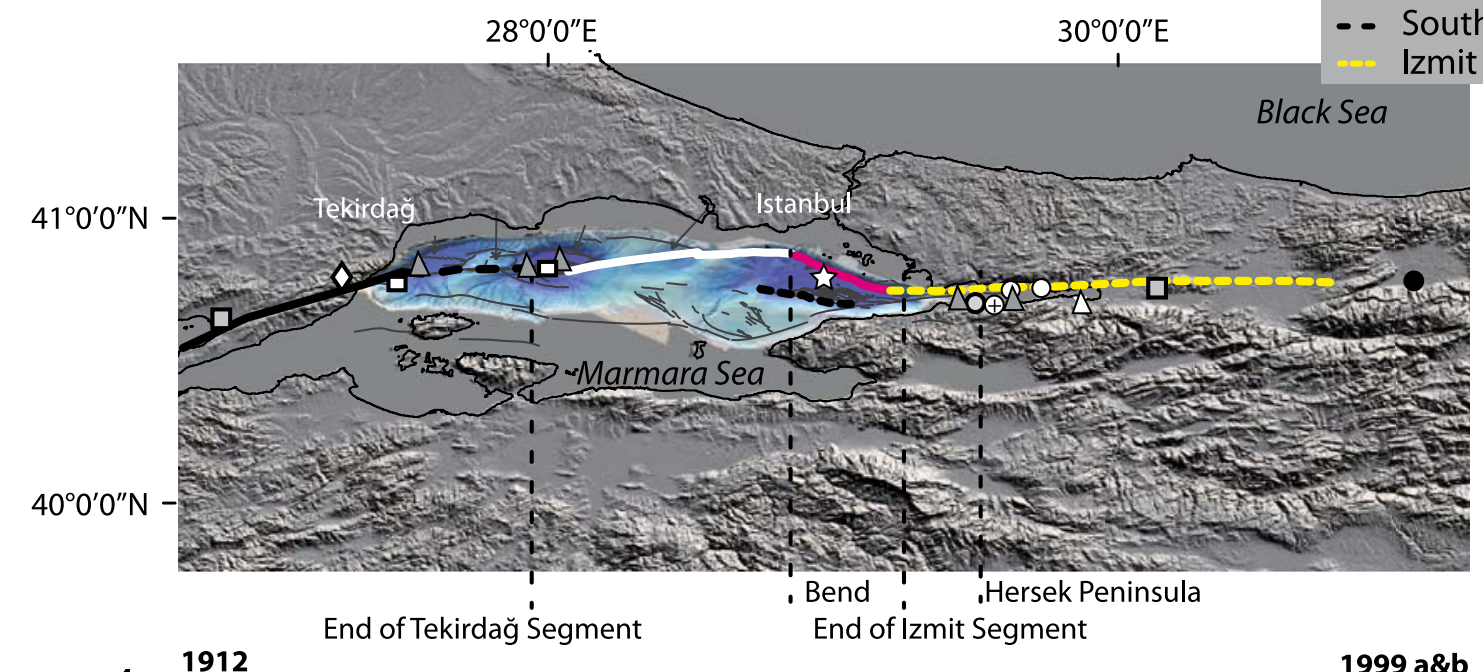

Sequence 4

1912

End of Tekirdağ Segment

1999 a\&b

Sequence 3 (option 1)

Sequence 3 (option 2)

Sequence 2

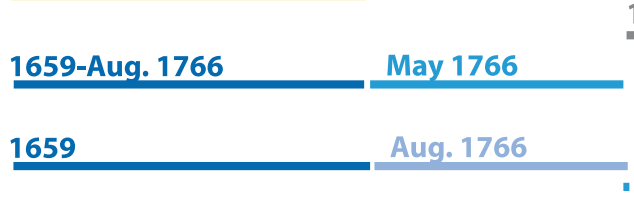

1894

1754-1719

Sequence 1

1509

989

Figure 11. Proposed rupture scenario for $M_{\mathrm{w}}>6.8$ earthquakes in the Marmara Sea between C.E. 740 and 1999 . Four sequences are observed, but only three are complete. The twentieth century westward propagation had not yet ruptured the eastern Marmara Sea. The scenario is compatible with a recent Coulomb stress analysis (Pondard et al., 2007) and description of damage (Ambraseys, 2002). Different shapes represent onland and submarine paleoseismological investigations of NAF ruptures in and around the Marmara Sea. The color version of this figure is available only in the electronic edition.

and the Çinarcık fault (Hubert-Ferrari et al., 2000; Parsons et al., 2000). Figure 11 also shows that no clear rupture propagation direction prevails and highlights the importance of the Çinarcik basin bounded to the north by the Çinarcik fault. Uçarkuş et al. (2010) considered the structure as $10 \mathrm{~km}$ wide stepover between the Izmit fault to the east and the Central fault to the west. This large stepover is a significant geometric barrier (King and Nábělek, 1985) for rupture propagation (Wesnousky, 2006) through the Marmara Sea, yet a large earthquake like that in 1509 C.E. seems to have propagated though the bend, rupturing the Çınarcık segment and the western part of the Izmit segment. The $30^{\circ}$ bend, located at the western part of the Izmit Segment, is of great importance because it may act as a permanent seismic barrier. In addition, some ruptures along the Çinarcık fault are out of sequence, as in the 1894 C.E. earthquake. The latter may be linked to the stress shadow induced by the May 1766 C.E. rupture of a secondary normal fault segment. The stress shadow may have delayed rupture along the Çinarcık segment by 130 years. Finally, segments seem to have similar activity, implying no specific creep, with the possible exception of the Central fault (Drab et al., 2012). Further paleoseismic studies in the Central basin are required to confirm this hypothesis, which has strong implications for hazard assessment in the Istanbul area, both in terms of the recurrence rate and the maximum magnitude of earthquakes along this segment.

\section{Conclusion}

We applied the concepts of subaquatic paleoseismology to two sediment cores located $20 \mathrm{~km}$ south of Istanbul in the Ç1narcik basin (Marmara Sea) to assess past fault rupture history along the Çınarcık segment of the NAF. Historical seismicity suggests that this segment has ruptured in $M_{\mathrm{w}}>7$ earthquakes. 
About $40 \%$ of the cores are composed of turbidites. Based on their distinctive sedimentological characteristics, their geographical extent, and synchronicity, and by the exclusion of other triggering mechanisms, the studied turbidites are concluded to be earthquake triggered. Core $\mathrm{Klg} 04$, located on the berm in the northern fault margin of the basin, likely records earthquakes rupturing the Çınarcık fault, whereas Klg03 may record earthquakes occurring on other faults and highlights the different sensitivity of both sites to earthquakes.

We estimated the timing of the first six sedimentary events using radiocarbon dating, radionuclides, and paleomagnetism measurements. Radiocarbon dating was calibrated using OxCal software and was corrected for marine reservoirs with a local reservoir correction of $400 \pm 50$ years, implying that the total reservoir age in the Marmara Sea is about 800 years for the last 2000 years.

The first earthquake-related turbidite recorded in the cores corresponds to the 1894 C.E. earthquake. Event E2 occurred between 1364 and 1511 C.E. and is probably related to the 1509 C.E. historical earthquake. Event E3 was dated 12681360 C.E. and was likely generated by the 1344 C.E. earthquake. Event E4, which occurred between 779 C.E. and 1041 C.E., was triggered by the 989 C.E. earthquake. Event E5, may be related to the 740 C.E. earthquake. Finally, event E6 (136-481 C.E.) may be related to the 478 C.E. earthquake.

The integration of our results enables us to propose a coherent scenario of past ruptures along the Çınarcık fault, which can be used for seismic-hazard assessment. Indeed, our observations help relocate some earthquakes for which the rupture segment is still under debate. We suggest that the 1766 C.E. earthquake did not occur along the Çınarcık fault, but that the 1344 C.E. earthquake was likely related to its activation. To obtain a better understanding of segment ruptures, a strengthened age model of sediment deposition in the Marmara Sea will require the acquisition of additional cores along the fault and in the basin.

\section{Data and Resources}

All historical earthquake data used in this article came from the published sources listed in the references. Maps were made using ArcGis 9.3 (http://www.esri.com/software/arcgis; last accessed August 2014). Age model was obtained using OxCal (Bronk Ramsey, 2007; also available at http://c14.arch .ox.ac.uk/embed.php?File=oxcal.html, last accessed October 2014). Cals3k.4 was obtained from http://www.gfz-potsdam .de/en/research/organizational-units/departments/department2/earths-magnetic-field/topics/field-models/calsxk/cals3k4/ (last accessed August 2014).

\section{Acknowledgments}

We first would like to thank Rolando Armijo who was the chief scientist of the Marmarascarps mission in 2002, from which we studied the two cores. We acknowledge Jean Luc Schneider for his help in core logging. We are grateful to Isabelle Billy, Joel Saint-Paul, and Olivier Ther for core sampling, realization of $\mathrm{x}$-ray scanner imagery, and $\mathrm{x}$-ray fluorescence (XRF) data acquisition. We would like to thank Elisabeth Michel and Elisabeth Tellier for their help on foraminifer extraction. We are also grateful to Catherine Kissel, who allowed us to finish our paleomagnetic measurements when the magnetometer of the Institut de Physique du Globe de Paris (IPGP) was not available. Radiocarbon dating was supported by the Centre National de la Recherche Scientifique-Institut National des Sciences de l'Univers (CNRS-INSU) Artemis program and done in the Artemis LMC14 laboratory as well as by the Crédit chercheur du fond national pour la Recherche Scientifique Belge under the project SEISMARM. The program CNRS/FRSFNRS CGRI supported grain size and acquisition in Liège (Belgium), and the École Normale Supérieure (ENS), UMR8538, provided additional financial support for data acquisition. We would like to thank Giuseppe Siani for fruitful discussions. Finally, we would like to thank Carl Brenner for improving the English grammar and expression.

\section{References}

Altınok, Y., B. Alpar, N. Özer, and H. Aykurt (2011). Revision of the tsunami catalogue affecting Turkish coasts and surrounding regions, Nat. Hazards Earth Syst. Sci. 11, no. 2, 273-291.

Ambraseys, N. (2001). The earthquake of 1509 in the Sea of Marmara, Turkey, revisited, Bull. Seismol. Soc. Am. 91, no. 6, 1397-1416.

Ambraseys, N. (2002). The seismic activity of the Marmara Sea region over the last 2000 years, Bull. Seismol. Soc. Am. 92, no. 1, 1-18.

Ambraseys, N. (2009). Earthquakes in the Mediterranean and Middle East, Cambridge University Press, New York, New York, 968 pp.

Ambraseys, N., and C. Finkel (1991). Long-term seismicity of Istanbul and of the Marmara Sea region, Terra Nova 3, no. 5, 527-539.

Armijo, R., B. Meyer, S. Navarro, G. King, and A. Barka (2002). Asymmetric slip partitioning in the Sea of Marmara pull-apart: A clue to propagation processes of the North Anatolian fault? Terra Nova 14, no. 2, 80-86.

Armijo, R., N. Pondard, B. Meyer, G. Uçarkuş, B. de Lepinay, J. Malavieille, S. Dominguez, M. Gutscher, S. Schmidt, C. Beck, et al. (2005). Submarine fault scarps in the Sea of Marmara pull-apart (North Anatolian fault): Implications for seismic hazard in Istanbul, Geochem. Geophys. Geosyst. 6, 1-29.

Bahr, A., F. Lamy, H. Arz, H. Kuhlmann, and G. Wefer (2005). Late glacial to Holocene climate and sedimentation history in the NW Black Sea, Mar. Geol. 214, no. 4, 309-322.

Barka, A., and K. Kadinsky-Cade (1988). Strike-slip fault geometry in Turkey and its influence on earthquake activity, Tectonics 7, no. 3, 663-684.

Beck, C., B. Mercier de Lépinay, J. Schneider, M. Cremer, N. Çağatay, E. Wendenbaum, S. Boutareaud, G. Ménot, S. Schmidt, O. Weber, et al. (2007). Late Quaternary co-seismic sedimentation in the Sea of Marmara's deep basins, Sediment. Geol. 199, nos 1/2, 65-89.

Bertrand, S., F. Charlet, E. Chapron, N. Fagel, and M. De Batist (2008). Reconstruction of the Holocene seismotectonic activity of the southern Andes from seismites recorded in Lago Icalma, Chile, $39^{\circ} \mathrm{S}$, Palaeogeogr. Palaeoclimatol. Palaeoecol. 259, nos. 2/3, 301-322.

Bertrand, S., L. Doner, S. Ön, U. Sancar, U. Schudack, S. Mischke, M. Çagatay, and S. Leroy (2011). Sedimentary record of coseismic subsidence in Hersek coastal lagoon (Izmit Bay, Turkey) and the late Holocene activity of the North Anatolian fault, Geochem. Geophys. Geosyst. 12, no. 6, Q06002, doi: 10.1029/2011GC003511.

Bronk Ramsey, C. (2007). Oxcal Program, v. 4.0, Radiocarbon Accelerator Unit, University of Oxford, United Kingdom, http://c14.arch.ox.ac.uk/ embed.php?File $=$ oxcal.html (last accessed October 2014).

Bulut, F., and M. Aktar (2007). Accurate relocation of Izmit earthquake $\left(M_{\mathrm{w}}=7.4,1999\right)$ aftershocks in Çınarcık basin using double difference method, Geophys. Res. Lett. 34, no. 10, L10307, doi: 10.1029/ 2007GL029611.

Çağatay, M., O. Algan, M. Sakinç, M. Eastoe, L. Egesel, N. Balkis, D. Ongan, and H. Caner (1999). A mid-late Holocene sapropelic sediment unit from the southern Marmara Sea shelf and its palaeoceanographic significance, Quaternary Sci. Rev. 18, nos. 4/5, 531-540.

Çağatay, M., L. Erel, L. Bellucci, A. Polonia, L. Gasperini, K. Eriş, U. Sancar, D. Biltekin, G. Uçarkuş, U. Ulgen, and E. Damcı 
(2012). Sedimentary earthquake records in the Izmit Gulf, Sea of Marmara, Turkey, Sediment. Geol. 282, 347-359.

Çağatay, M., K. Eriş, W. Ryan, U. Sancar, A. Polonia, S. Akcer, D. Biltekin, L. Gasperini, N. Görür, G. Lericolais, and E. Bard (2009). Late Pleistocene-Holocene evolution of the northern shelf of the Sea of Marmara, Mar. Geol. 265, nos. 3/4, 87-100.

Çă̆atay, M., N. Görür, O. Algan, C. Eastoe, A. Tchapalyga, D. Ongan, T. Kuhn, and I. Kuşcu (2000). Late Glacial-Holocene palaeoceanography of the Sea of Marmara: Timing of connections with the Mediterranean and the Black Seas, Mar. Geol. 167, nos. 3/4, 191-206.

Çağatay, M., M. Özcan, and E. Güngör (2004). Pore-water and sediment geochemistry in the Marmara Sea (Turkey): Early diagenesis and diffusive fluxes, Geochem. Explor. Environ. Anal. 4, no. 3, 213-225.

Calvert, S. (1990). Geochemistry and origin of the Holocene sapropel in the Black Sea, in Facets of Modern Biogeochemistry, Springer-Verlag, Berlin, Germany, 326-352.

Campos, C., C. Beck, C. Crouzet, F. Demory, A. Van Welden, and K. Eris (2013). Deciphering hemipelagites from homogenites through anisotropy of magnetic susceptibility. Paleoseismic implications (Sea of Marmara and Gulf of Corinth), Sediment. Geol. 292, 1-14.

Carton, H., S. C. Singh, A. Hirn, S. Bazin, B. de Voogd, A. Vigner, A. Ricolleau, S. Cetin, N. Ocakoglu, F. Karakoc, and V. Sevilgen (2007). Seismic imaging of the three-dimensional architecture of the Çınarcık basin along the North Anatolian fault, J. Geophys. Res. 112, no. B6, B06101, doi: 10.1029/2006JB004548.

Cogné, J. (2003). Paleomac: A Macintosh application for treating paleomagnetic data and making plate reconstructions, Geochem. Geophys. Geosyst. 4, no. 1, 1007.

Cramp, A., and G. O'Sullivan (1999). Neogene sapropels in the Mediterranean: A review, Mar. Geol. 153, nos. 1/4, 11-28.

Drab, L. (2012). Étude multidisciplinaire le long de la Faille Nord Anatolienne, Turquie: Paléosismologie marine et paléomagnétisme en Mer de Marmara; Étude géomorphologique du décalage de la rivière Kizilirmak par utilisation des isotopes cosmogéniques, Ph.D. thesis, Ecole Normale Supérieure, Université Paris Sud XI (in French).

Drab, L., J. Carlut, A. Hubert-Ferrari, P. Martinez, G. LePoint, and M. El Ouahabi (2015). Paleomagnetic and geochemical record from cores from the Sea of Marmara, Turkey: Age constraints and implications of sapropelic deposition on early diagenesis, Marine Geology 360, 40-54, 0025-3227, doi: 10.1016/j.margeo.2014.12.002.

Drab, L., A. Hubert, S. Schmidt, and P. Martinez (2012). The earthquake sedimentary record in the western part of the Sea of Marmara, Turkey, Nat. Hazards Earth Syst. Sci. 12, no. 4, 1235-1254.

Eastwood, W., N. Roberts, and H. Lamb (1998). Palaeoecological and archaeological evidence for human occupance in southwest Turkey: The Beyşehir occupation phase, Anatolian Stud. 48, 69-86.

Eginitis, M. (1894). Earthquake report, Technical report, Prime Minister's Archive, Turkey.

Evans, M., and F. Heller (2003). Environmental Magnetism: Principles and Applications of Enviromagnetics, Vol. 86, Academic Press, London, United Kingdom.

Folk, R. (1968). Petrology of Sedimentary Rocks, Hemphill's Austin, Austin, Texas.

Fraser, J., K. Vanneste, and A. Hubert-Ferrari (2010). Recent behavior of the North Anatolian fault: Insights from an integrated paleoseismological data set, J. Geophys. Res. 115, no. B9, B09316, doi: 10.1029/ 2009JB006982.

Gibbon, E. (1829). The History of the Decline and Fall of the Roman Empire, Vol. 4, J. \& J. Harper, New York.

Goldfinger, C. (2011). The record of large turbidites and their relevance to the history of earthquakes, Annu. Rev. Mar. Sci. 3, no. 1, doi: 10.1146/ annurev-marine-120709-142852.

Goldfinger, C., K. Grijalva, R. Bürgmann, A. Morey, J. Johnson, C. Nelson, J. Gutiérrez-Pastor, A. Ericsson, E. Karabanov, J. Chaytor, et al. (2008). Late Holocene rupture of the northern San Andreas fault and possible stress linkage to the Cascadia subduction zone, Bull. Seismol. Soc. Am. 98, no. 2, 861-889.
Goldfinger, C., C. H. Nelson, A. E. Morey, J. E. Johnson, J. R. Patton, E. Karabanov, J. Gutierrez-Pastor, A. T. Eriksson, E. Gràcia, G. Dunhill, et al. (2012). Turbidite event history: Methods and implications for Holocene paleoseismicity of the Cascadia subduction zone, U.S. Geol. Surv. Prof. Paper 1661-F, 170 pp., available at http://pubs.usgs.gov/ pp/pp1661f/ (last accessed August 2014).

Gorsline, D., T. De Diego, and E. Nava-Sanchez (2000). Seismically triggered turbidites in small margin basins: Alfonso basin, western Gulf of California and Santa Monica basin, California borderland, Sediment. Geol. 135, nos. 1/4, 21-35.

Gracia, E., A. Vizcaino, C. Escutia, A. Asioli, A. Rodes, R. Pallas, J. GarciaOrellana, S. Lebreiro, and C. Goldfinger (2010). Holocene earthquake record offshore Portugal (SW Iberia): Testing turbidite paleoseismology in a slow-convergence margin, Quaternary Sci. Rev. 29, no. 910, $1156-1172$.

Guidoboni, E., and A. Comastri (2005). Catalogue of Ancient Earthquakes and Tsunamis in the Mediterranean Area up from the 11th to the 15th Century, Istituto nazionale di geofisica e vulcanologia, Roma, Italy.

Hebert, H., F. Schindele, Y. Altınok, B. Alpar, and C. Gazioglu (2005). Tsunami hazard in the Marmara Sea (Turkey): A numerical approach to discuss active faulting and impact on the Istanbul coastal areas, Mar. Geol. 215, nos. 1/2, 23-43.

Hubert-Ferrari, A., A. Barka, E. Jacques, S. Nalbant, B. Meyer, R. Armijo, P. Tapponnier, and G. King (2000). Seismic hazard in the Marmara Sea region following the 17 August 1999 Izmit earthquake, Nature 404, no. $6775,269-273$.

Ince, G. (2011). The relationship between the performance of soil conditions and damage following an earthquake: A case study in Istanbul, Turkey, Nat. Hazards Earth Syst. Sci. 11, 1745-1758.

Kagan, E., M. Stein, A. Agnon, and C. Ramsey (2010). Paleoearthquakes as anchor points in Bayesian radiocarbon deposition models: A case study from the Dead Sea, Radiocarbon 52, no. 3, 1018-1026.

Kazanci, N., S. Leroy, O. Ileri, O. Emre, M. Kibar, and S. Oncel (2004). Late Holocene erosion in NW Anatolia from sediments of Lake Manyas, Lake Ulubat and the southern shelf of the Marmara Sea, Turkey, Catena 57, no. 3, 277-308.

King, G., and J. Nábělek (1985). Role of fault bends in the initiation and termination of earthquake rupture, Science 228, no. 4702, 984-987.

Kirschvink, J. (1980). The least-squares line and plane and the analysis of palaeomagnetic data, Geophys. J. Roy. Astron. Soc. 62, no. 3, 699-718.

Klinger, Y., K. Sieh, E. Altunel, A. Akoglu, A. Barka, T. Dawson, T. Gonzalez, A. Meltzner, and T. Rockwell (2003). Paleoseismic evidence of characteristic slip on the western segment of the North Anatolian fault, Turkey, Bull. Seismol. Soc. Am. 93, no. 6, 2317-2332.

Korte, M., and C. Constable (2011). Improving geomagnetic field reconstructions for 0-3 ka, Phys. Earth Planet. In. 188, no. 3, 247-259.

Kozaci, O., E. Altunel, K. Clahan, O. Yonlu, S. Sundermann, W. Lettis, J. Turner, J. Altekruse, I. Gumus, and S. Lindvall (2010). A late Holocene slip rate of the North Anatolian fault, Hersek Peninsula, Izmit Bay, Turkey, in AGU Fall Meeting Abstracts, Vol. 1, 2236.

Kozaci, Ö., E. Altunel, S. Lindvall, C. Brankman, and W. Lettis (2011). The North Anatolian fault on Hersek Peninsula, Turkey: Its geometry and implications on the 1999 Izmit earthquake rupture propagation, Turk. J. Earth Sci. 20, 359-378.

Kurt, H., C. Sorlien, L. Seeber, M. Steckler, D. Shillington, G. Cifci, M.-H. Cormier, J.-X. Dessa, O. Atgin, and D. Dondurur, et al. (2013). Steady late quaternary slip rate on the Çnarcık section of the North Anatolian fault near Istanbul, Turkey, Geophys. Res. Lett. 40, no. 17, 4555-4559.

Larrasoaña, J., A. Roberts, J. Stoner, C. Richter, and R. Wehausen (2003). A new proxy for bottom-water ventilation in the eastern Mediterranean based on diagenetically controlled magnetic properties of sapropelbearing sediments, Palaeogeogr. Palaeoclimatol. Palaeoecol. 190, 221-242.

Le Pichon, X., A. Sengör, E. Demirbag, C. Rangin, C. Imren, R. Armijo, N. Görür, N. Çagatay, B. Mercier de Lepinay, B. Meyer, et al. (2001). The active main Marmara fault, Earth Planet. Sci. Lett. 192, no. 4, 595-616. 
Leroy, S., N. Kazanc1, O. leri, M. Kibar, O. Emre, E. McGee, and H. Griffiths (2002). Abrupt environmental changes within a late Holocene lacustrine sequence south of the Marmara Sea (Lake Manyas, NW Turkey): Possible links with seismic events, Mar. Geol. 190, nos. 1/2, 531-552.

Lima, A., J. Hubeny, C. M. Reddy, J. King, K. Hughen, and T. Eglinton (2005). High-resolution historical records from Pettaquamscutt River basin sediments: $1 .{ }^{210} \mathrm{~Pb}$ and varve chronologies validate record of ${ }^{137} \mathrm{Cs}$ released by the Chernobyl accident, Geochimica et Cosmochimica Acta 69, no. 7, 1803-1812.

Masson, D., R. Arzola, J. Wynn, E. Hunt, and P. Weaver (2011). Seismic triggering of landslides and turbidity currents offshore Portugal, Geochem. Geophys. Geosyst. 12, no. 12, Q12011, doi: 10.1029/ $2011 \mathrm{GC} 003839$.

McCalpin, J. (1996). Paleoseismology, Academic Press, New York.

McHugh, C., L. Seeber, N. Braudy, M. Cormier, M. Davis, J. Diebold, N. Dieudonne, R. Douilly, S. Gulick, M. Hornbach, et al. (2011). Offshore sedimentary effects of the 12 January 2010 Haiti earthquake, Geology 39, no. 8, 723-726.

McHugh, C., L. Seeber, M. Cormier, J. Dutton, N. Çağatay, A. Polonia, W. Ryan, and N. Gorur (2006). Submarine earthquake geology along the North Anatolia fault in the Marmara Sea, Turkey: A model for transform basin sedimentation, Earth Planet. Sci. Lett. 248, nos. 3/4, 661-684.

Meghraoui, M., M. Aksoy, H. Akyüz, M. Ferry, A. Dikbaş, and E. Altunel (2012). Paleoseismology of the North Anatolian fault at Güzelköy (Ganos segment, Turkey): Size and recurrence time of earthquake ruptures west of the Sea of Marmara, Geochem. Geophys. Geosyst. 13, no. 4, Q04005, doi: 10.1029/2011GC003960.

Mudie, P., F. Marret, A. Aksu, R. Hiscott, and H. Gillespie (2007). Palynological evidence for climatic change, anthropogenic activity and outflow of Black Sea water during the late Pleistocene and Holocene: Centennial- to decadal-scale records from the Black and Marmara Seas, Quaternary Int. 167/168, 73-90.

Mudie, P., A. Rochon, and A. Aksu (2002). Pollen stratigraphy of Late Quaternary cores from Marmara Sea: Land-sea correlation and paleoclimatic history, Mar. Geol. 190, nos. 1/2, 233-260.

Nakajima, T., and Y. Kanai (2000). Sedimentary features of seismoturbidites triggered by the 1983 and older historical earthquakes in the eastern margin of the Japan Sea, Sediment. Geol. 135, nos. 1/4, 1-19.

Özaksoy, V., Ö. Emre, C. Yıldırım, A. Doğan, S. Özalp, and F. Tokay (2010). Sedimentary record of late Holocene seismicity and uplift of Hersek restraining bend along the North Anatolian fault in the Gulf of Izmit, Tectonophysics 487, no. 1, 33-45.

Palike, H., N. Shackleton, and U. Rohl (2001). Astronomical forcing in late Eocene marine sediments, Earth Planet. Sci. Lett. 193, nos. 3/4, 589-602.

Parsons, T. (2004). Recalculated probability of $M_{\mathrm{w}}>7$ earthquakes beneath the Sea of Marmara, Turkey, J. Geophys. Res. 109, no. B5, B05304, doi: 10.1029/2003JB002667.

Parsons, T., S. Toda, R. Stein, A. Barka, and J. Dieterich (2000). Heightened odds of large earthquakes near Istanbul: An interaction-based probability calculation, Science $\mathbf{2 8 8}$, no. 5466, 661-665.

Pondard, N., R. Armijo, G. King, B. Meyer, and F. Flerit (2007). Fault interactions in the Sea of Marmara pull-apart (North Anatolian fault): Earthquake clustering and propagating earthquake sequences, Geophys. J. Int. 171, no. 3, 1185-1197.

Reilinger, R., S. McClusky, P. Vernant, S. Lawrence, S. Ergintav, R. Cakmak, H. Ozener, F. Kadirov, I. Guliev, and R. Stepanyan, et al. (2006). GPS constraints on continental deformation in the Africa-Arabia-Eurasia continental collision zone and implications for the dynamics of plate interactions, J. Geophys. Res. 111, no. B5, B05411, doi: 10.1029/ 2005JB004051.

Reimer, P., and F. McCormac (2002). Marine radiocarbon reservoir corrections for the Mediterranean and Aegean Seas, Radiocarbon 44, no. 1, $159-166$.

Reimer, P., E. Bard, A. Bayliss, J. Beck, P. Blackwell, B. C. Ramsey, H. Cheng, R. Edwards, M. Friedrich, P. Grootes, et al. (2013). Intcal13 and marine13 radiocarbon age calibration curves $0-50,000$ years cal BP, Radiocarbon 55, no. 4, 1869-1887.
Robbins, J. (1978). Geochemical and geophysical applications of radioactive lead, The Biogeochem. Lead Environ. 1, 285-337.

Rockwell, T., A. Barka, T. Dawson, S. Akyuz, and K. Thorup (2001). Paleoseismology of the Gazikoy-Saros segment of the North Anatolia fault, northwestern Turkey: Comparison of the historical and paleoseismic records, implications of regional seismic hazard, and models of earthquake recurrence, J. Seismol. 5, no. 3, 433-448.

Rockwell, T., D. Ragona, G. Seitz, R. Langridge, M. Aksoy, G. Uçarkuş, M. Ferry, A. Meltzner, Y. Klinger, M. Meghraoui, et al. (2009). Palaeoseismology of the North Anatolian fault near the Marmara Sea: Implications for fault segmentation and seismic hazard, Geol. Soc. Lond. Sp. Publ. 316, no. 1, 31-54.

Rohling, E., and F. Hilgen (1991). The eastern Mediterranean climate at times of sapropel formation: A review, Geologie en Mijnbouw 70, no. 3, 253-264.

Sarı, E., and M. Çağatay (2006). Turbidites and their association with past earthquakes in the deep Çinarcık basin of the Marmara Sea, GeoMarine Lett. 26, no. 2, 69-76.

Schmidt, S., H. Howa, A. Mouret, F. Lombard, P. Anschutz, and L. Labeyrie (2009). Particle fluxes and recent sediment accumulation on the Aquitanian margin of Bay of Biscay, Continent. Shelf Res. 29, no. 8, 1044-1052.

Sengör, A., O. Tüysüz, C. Imren, M. Sakinç, H. Eyidogan, N. Görür, X. Le Pichon, and C. Rangin (2005). The North Anatolian fault: A new look, Annu. Rev. Earth Planet. Sci. 33, 37-112.

Shiki, T., F. Kumon, Y. Inouchi, Y. Kontani, T. Sakamoto, M. Tateishi, H. Matsubara, and K. Fukuyama (2000). Sedimentary features of the seismoturbidites, Lake Biwa, Japan, Sediment. Geol. 135, nos. 1/4, 37-50.

Siani, G., M. Paterne, M. Arnold, E. Bard, B. Metivier, N. Tisnerat, and F. Bassinot (2000). Radiocarbon reservoir ages in the Mediterranean Sea and Black Sea, Radiocarbon 42, no. 2, 271-280.

Siani, G., M. Paterne, E. Michel, R. Sulpizio, A. Sbrana, M. Arnold, and G. Haddad (2001). Mediterranean Sea surface radiocarbon reservoir age changes since the last glacial maximum, Science 294, no. 5548, 1917-1920.

Smith, A., T. Taymaz, F. Oktay, H. Yüce, B. Alpar, H. Başaran, J. Jackson, S. Kara, and M. Şimşek (1995). High-resolution seismic profiling in the Sea of Marmara (northwest Turkey): Late Quaternary sedimentation and sea-level changes, Geol. Soc. Am. Bull. 107, no. 8, 923-936.

Sperazza, M., J. Moore, and M. Hendrix (2004). High-resolution particle size analysis of naturally occurring very fine-grained sediment through laser diffractometry, J. Sediment. Res. 74, no. 5, 736-743.

Stuiver, M., G. W. Pearson, and T. F. Braziunas (1986). Radiocarbon age calibration of marine samples back to $9000 \mathrm{cal} \mathrm{yr}$ BP, Radiocarbon 28, no. 2B, 980-1021.

Sugai, T., Y. Awata, S. Toda, O. Emre, A. Dogan, S. Ozalp, T. Haraguchi, H. Kinoshita, K. Takada, and M. Yamaguchi (2001). Paleoseismic investigation of the 1999 Düzce earthquake fault at Lake Efteni, North Anatolian fault system, Turkey, Annual Report on Active Fault and Paleoearthquake Researches, 339-351.

Tauxe, L., and D. V. Kent (1984). Properties of a detrital remanence carried by haematite from study of modern river deposits and laboratory redeposition experiments, Geophys. J. Roy. Astron. Soc. 76, no. 3, 543-561.

Tema, E., and D. Kondopoulou (2011). Secular variation of the Earth's magnetic field in the Balkan region during the last eight millennia based on archaeomagnetic data, Geophys. J. Int. 186, no. 2, 603-614.

Tolun, L., M. Çağatay, and W. Carrigan (2002). Organic geochemistry and origin of Late Glacial-Holocene sapropelic layers and associated sediments in Marmara Sea, Mar. Geol. 190, nos. 1/2, 47-60.

Uçarkuş, G. (2010). Active faulting and earthquake scarps along the North Anatolian fault in the Sea of Marmara, Ph.D. thesis, Istanbul Technical University.

Uçarkuş, G., Z. Çakır, and R. Armijo (2010). Western termination of the $M_{\mathrm{w}}=7.4,1999$ Izmit earthquake rupture: Implications for the expected large earthquake in the Sea of Marmara, Turk. J. Earth Sci. 20, no. 4, 379-394.

Valsecchi, V., M. Sanchez-Goni, and L. Londeix (2012). Vegetation dynamics in the northeastern Mediterranean region during the past $23000 \mathrm{yr}$ : Insight from a new pollen record from the Sea of Marmara (core MD01-2430), Clim. Past Discuss. 8, 4183-4221. 
van Welden, A., C. Beck, J. Reyss, S. Bushati, R. Koci, F. Jouanne, and J. Mugnier (2008). The last 500 year of sedimentation in Shkodra Lake (Albania/Montenegro): Paleoenvironmental evolution and potential for paleoseismicity studies, J. Paleolimnol. 40, no. 2, 619-633.

Vidal, L., G. Menot, C. Joly, H. Bruneton, F. Rostek, M. N. Çağatay, C. Major, and E. Bard (2010). Hydrology in the Sea of Marmara during the last $23 \mathrm{ka}$ : Implications for timing of Black Sea connections and sapropel deposition, Paleoceanography 25, no. 1, PA1205.

Vlag, P., P. Kruiver, and M. Dekkers (2004). Evaluating climate change by multivariate statistical techniques on magnetic and chemical properties of marine sediments (Azores region), Palaeogeogr. Palaeoclimatol. Palaeoecol. 212, nos. 1/2, 23-44.

Walling, D. (2006). Human impact on land-ocean sediment transfer by the world's rivers, Geomorphology 79, nos. 3/4, 192-216.

Wesnousky, S. (2006). Predicting the endpoints of earthquake ruptures, Nature 444, no. 7117, 358-360.

Yalçıner, A., B. Alpar, Y. Altınok, İ. Özbay, and F. Imamura (2002). Tsunamis in the Sea of Marmara: Historical documents for the past, models for the future, Mar. Geol. 190, no. 1, 445-463.

Yücel, M., G. Luther, and W. Moore (2010). Earthquake-induced turbidite deposition as a previously unrecognized sink for hydrogen sulfide in the Black Sea sediments, Mar. Chem. 121, no. 1, 176-186.

Ziegler, M., T. Jilbert, G. de Lange, L. Lourens, and G. Reichart (2008) Bromine counts from XRF scanning as an estimate of the marine organic carbon content of sediment cores, Geochem. Geophys. Geosyst. 9, no. 5, Q05009, doi: 10.1029/2007GC001932.

Appendix

Figure A1 presents the Zijderveld diagrams for cores $\mathrm{Klg} 03$ and $\mathrm{Klg} 04$, and Figure A2 displays the correlation between the $\mathrm{Klg} 03$ and $\mathrm{Klg} 04$ cores, and the $\mathrm{C} 15$ core previously studied by Sarı and Çağatay (2006).

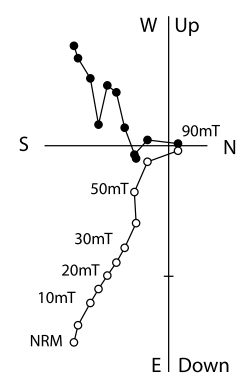

$\mathrm{Klg} 04-18 \mathrm{~cm}$
Scale: $1 \times 10^{-2} \mathrm{~A} / \mathrm{m}$

Figure A1. Zijderveld diagram of demagnetization for cores $\mathrm{Klg} 04$ at $18 \mathrm{~cm}$ in depth and $\mathrm{Klg} 03$ at $160 \mathrm{~cm}$ in depth. The solid circles represent the projection on the horizontal plane, and the open circles the projection on the vertical plane.

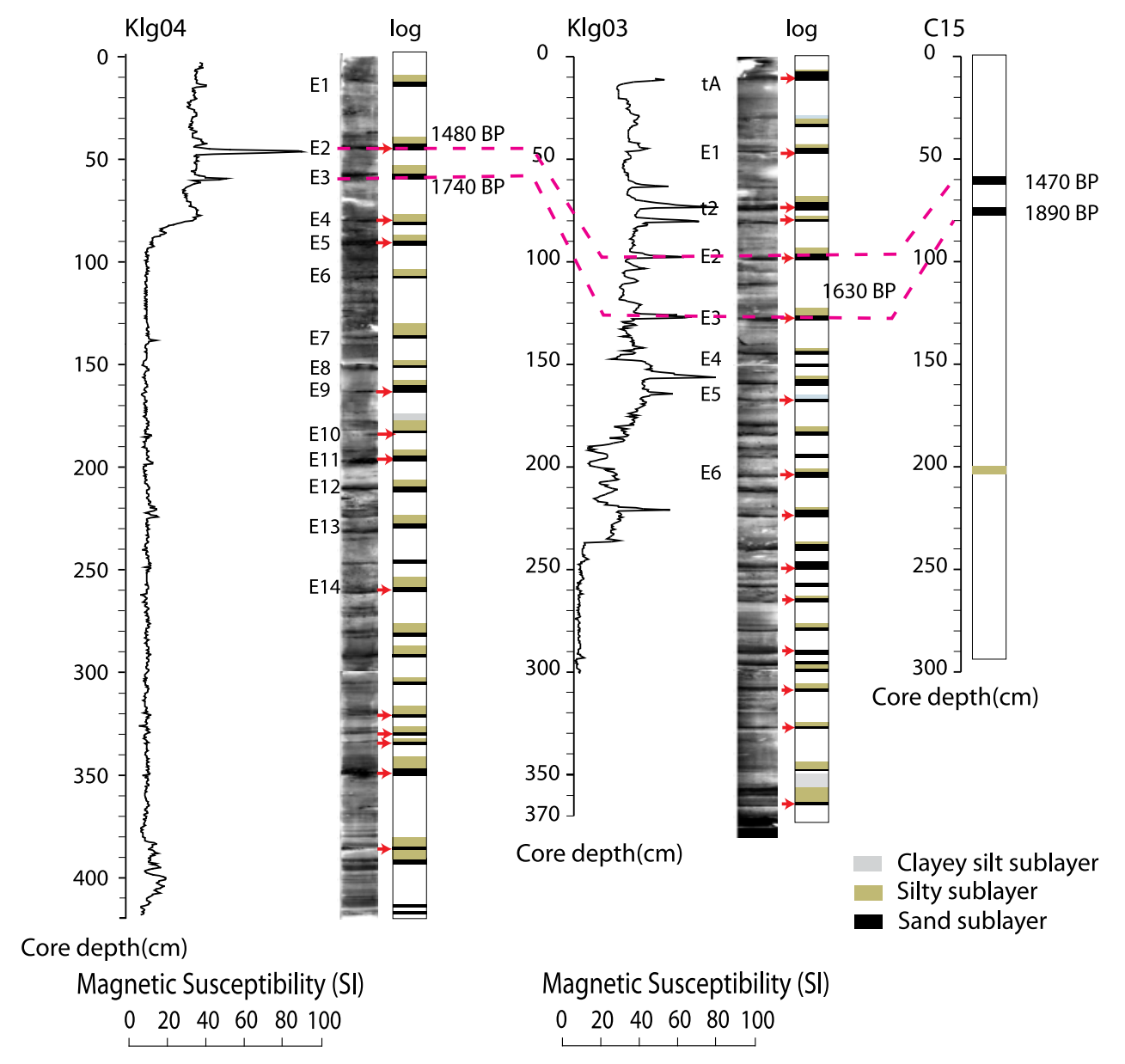

Figure A2. Correlation between cores $\mathrm{Klg} 03, \mathrm{Klg} 04$, and $\mathrm{C} 15$ (Sarı and Çağatay, 2006). Ages are represented as uncalibrated. The color version of this figure is available only in the electronic edition. 
École Normale Supérieure

Laboratoire de Géologie

24 rue Lhomond

75231 Paris, Cedex 05

France

(L.D.)

Département de Géographie

Université de Liège

Allée du 6 août, 2, Bât. B11

Sart Tilman B 4000 Liège

Belgium

(A.H.-F., M.E.)
UMR CNRS 5805 EPOC

OASU-Université de Bordeaux Allée Geoffroy Saint-Hilaire CS 50023

33615 Pessac Cedex, France

Site de Talence

Université Bordeaux 1

Avenue des Facultés

33405 Talence Cedex, France

(S.S., P.M.)

Institut de Physique du globe de Paris (IPGP)

1 , rue Jussieu

75238 Paris, Cedex 05

France

(J.C.) 